UMETNOSTNOZGODOVINSKI INŠTITUT FRANCETA STELETA ZRC SAZU

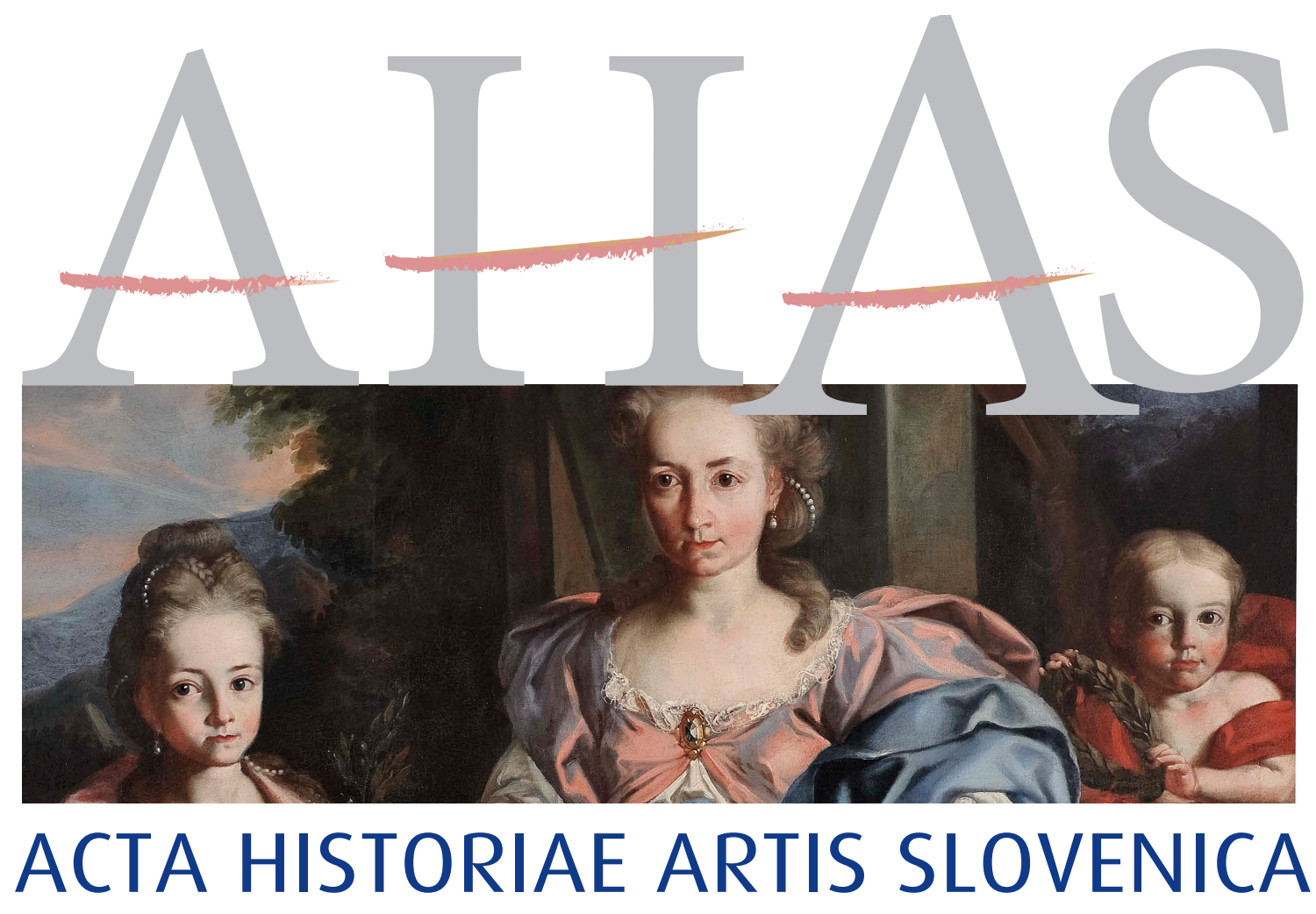

$23 \mid 1 \cdot 2018$ 
Umetnostnozgodovinski inštitut Franceta Steleta ZRC SAZU

France Stele Institute of Art History ZRC SAZU

\section{ACTA HISTORIAE ARTIS SLOVENICA}

$23 \mid 1 \cdot 2018$ 
Acta historiae artis Slovenica, 23/1, 2018

Znanstvena revija za umetnostno zgodovino / Scholarly Journal for Art History

ISSN 1408-0419 (tiskana izdaja / print edition)

ISSN 2536-4200 (spletna izdaja / web edition)

Izdajatelj / Issued by

ZRC SAZU, Umetnostnozgodovinski inštitut Franceta Steleta/

ZRC SAZU, France Stele Institute of Art History

Založnik / Publisher

Založba ZRC

Urednica / Editor

Tina Košak

Uredniški odbor / Editorial board

Tina Košak, Ana Lavrič, Barbara Murovec, Mija Oter Gorenčič, Blaž Resman, Helena Seražin

Mednarodni svetovalni odbor / International advisory board

Günter Brucher (Salzburg), Iris Lauterbach (München), Hellmut Lorenz (Wien), Milan Pelc (Zagreb),

Paola Rossi (Venezia), Sergio Tavano (Gorizia-Trieste), Barbara Wisch (Cortland, USA)

Lektoriranje / Language editing

Tina Bratuša, Aleksandra Čehovin, Kirsten Hempkin, Amy Anne Kennedy, Blaž Resman, Anke Schlecht

Prevodi / Translations

Nicole Burgund, Tina Košak, Andreja Rakovec, Nika Vaupotič, Polona Vidmar

Oblikovna zasnova in prelom / Design and layout

Andrej Furlan

Naslov uredništva / Editorial office address

Acta historiae artis Slovenica

Novi trg 2, p. p. 306, SI -1001 Ljubljana, Slovenija

E-pošta / E-mail: ahas@zrc-sazu.si

Spletna stran / Web site: http://uifs1.zrc-sazu.si

Revija je indeksirana $v$ / Journal is indexed in

Scopus, ERIH PLUS, EBSCO Publishing, IBZ, BHA

Letna naročnina / Annual subscription: $35 €$

Posamezna enojna številka / Single issue: $25 €$

Letna naročnina za študente in dijake: $25 €$

Letna naročnina za tujino in ustanove / Annual Subscription outside Slovenia, institutions: $48 €$

Naročila sprejema / For orders contact

Založba ZRC

Novi trg 2, p. p. 306, SI-1001, Slovenija

E-pošta / E-mail: zalozba@zrc-sazu.si

AHAS izhaja s podporo Javne agencije za raziskovalno dejavnost Republike Slovenije.

AHAS is published with the support of the Slovenian Research Agency.

(c) 2018, ZRC SAZU, Umetnostnozgodovinski inštitut Franceta Steleta, Založba ZRC, Ljubljana

Tisk / Printed by Cicero d. o. 0., Begunje

Naklada / Print run: 400 


\section{VSEBINA}

\section{Contents}

Milček Komelj

Ob 70-letnici Umetnostnozgodovinskega inštituta Franceta Steleta.

Nagovor na slavnostni akademiji 14. decembra 2017 v Prešernovi dvorani SAZU .......................................

France Stele Institute of Art History's 70th Anniversary.

The Opening Speech at the Celebration on 14 December 2017 at the Prešeren Hall SAZU

\section{DISSERTATIONES}

Mija Oter Gorenčič

Pro remedio et pro salute animae nostrae. Memoria v srednjeveškem umetnostnem okrasju cisterce $v$ Stični kot odsev tesne povezanosti s plemstvom

Pro remedio et pro salute animae nostrae. Memoria in Medieval Architectural

Decoration of the Stična Cistercian Monastery as a Reflection of its Close Connection

with the Nobility

Janez Premk

Maribor Synagogue Reexamined

Mariborska sinagoga pod drobnogledom

Friedrich Polleroß

Die Immaculata, Kaiser Leopold I., und ein römisches Thesenblatt der Laibacher Franziskaner 93

Brezmadežna, cesar Leopold I. in rimski tezni list ljubljanskih frančiškanov

Barbara Murovec

Historizirana podoba naročnika. Attemsova družinska portreta iz brežiškega gradu in Rembov avtoportret

The Patron's Historized Image. Attems' Family Portraits and Remp's

Self-Portrait in the Brežice (Rann) Castle

Vesna Krmelj

France Stele v luči mladostne korespondence z Izidorjem Cankarjem..

An Insight into France Stele through his Early Adulthood Correspondence with Izidor Cankar 
Tanja Zimmermann

Oto Bihalji-Merin and the Concept of the "Naïve" in the 1950s.

Bridging Socialist Realism and Non-Figurative Art

Oto Bihalji-Merin in koncept »naivnih $v$ petdesetih letih 20. stoletja.

Most med socialističnim realizmom in nefiguralno umetnostjo

Jasmina Čubrilo

Yugoslav: Toponym or Ideology in Miodrag B. Protićs Art-Historical

Systematization of 20th-Century Art

Jugoslovansko: toponim ali ideologija $v$ umetnostnozgodovinski sistematizaciji

umetnosti 20. stoletja $v$ besedilih Miodraga B. Protića.

\section{MISCELLANEA}

Damjan Prelovšek

Plečnikov prizidek $k$ bratovi hiši v Trnovem

Jože Plečnik's Extension of his Brother Andrej's House in Trnovo

\section{APPARATUS}

Izvlečki in ključne besede/Abstracts and keywords

Sodelavci / Contributors

Viri ilustracij / Photographic credits 


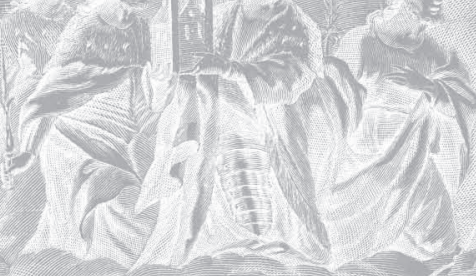

絖
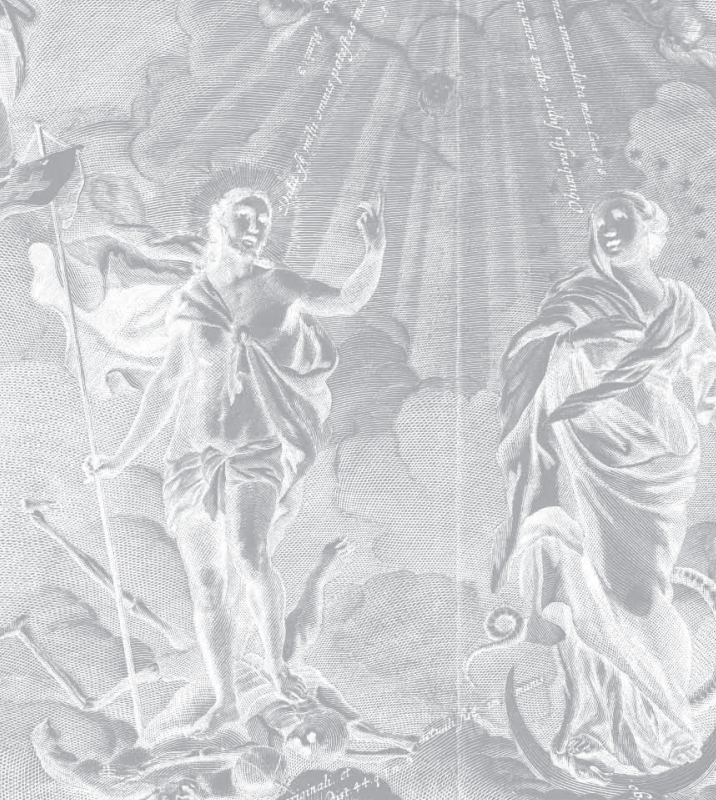

\section{DISSERTATIONES}

\section{.}

.
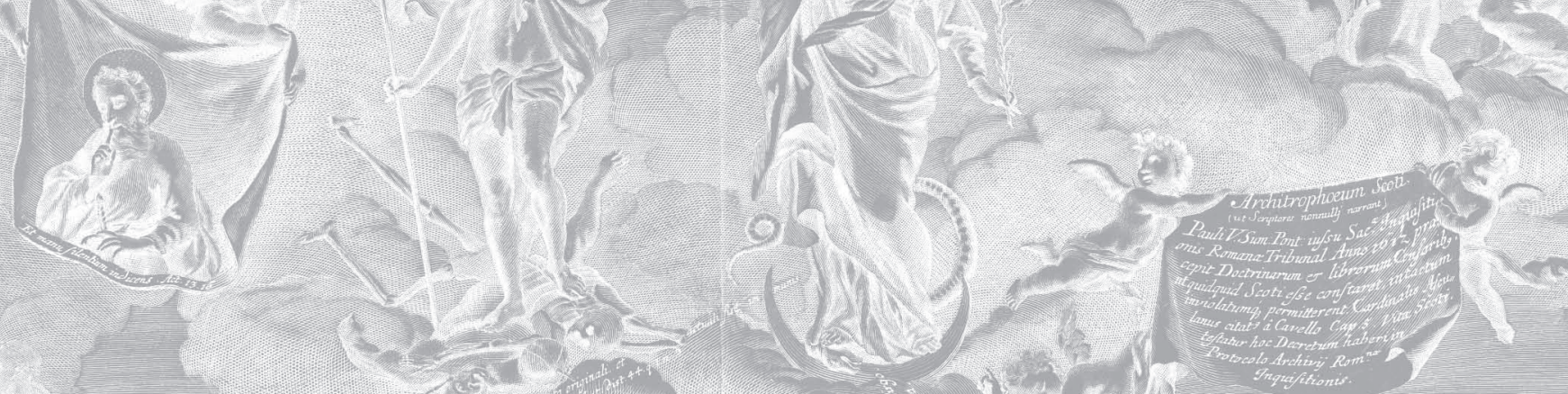

a 9
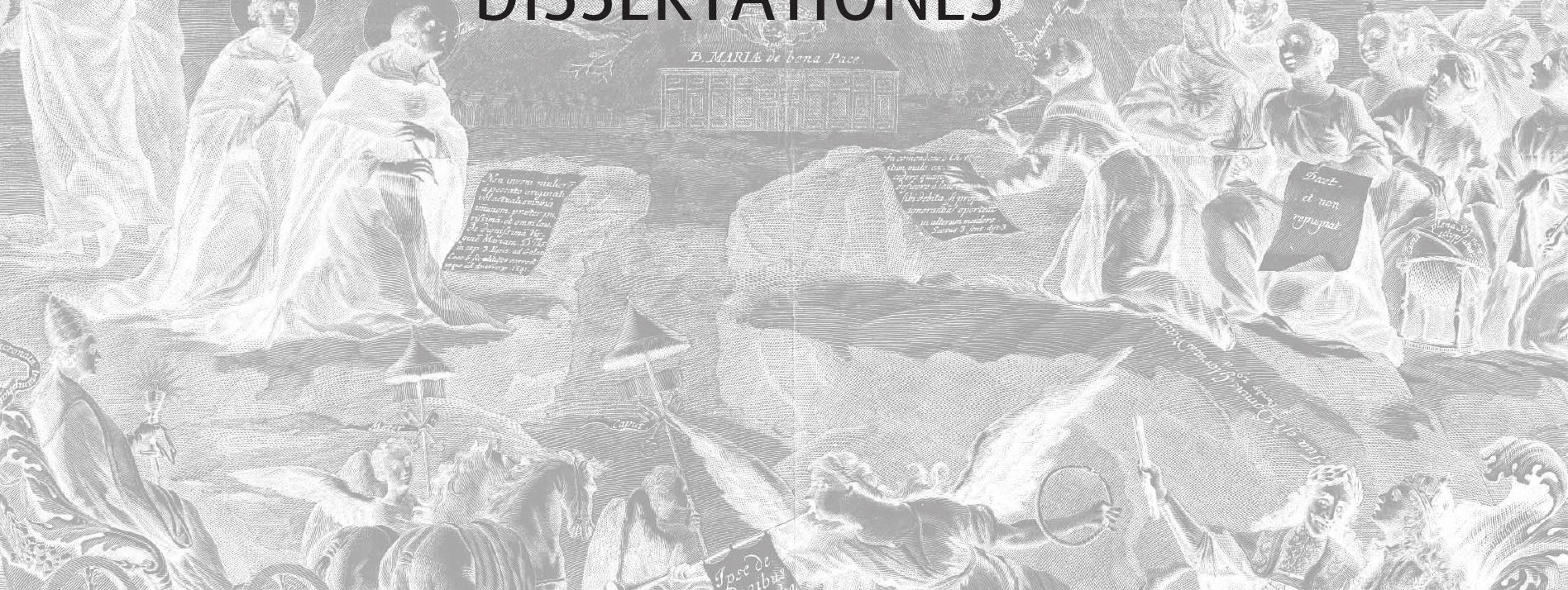
Fin

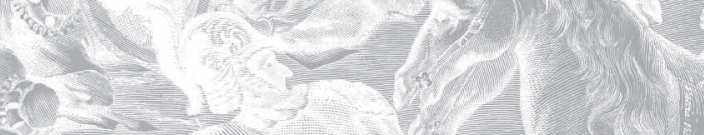




\title{
Yugoslav: Toponym or Ideology in Miodrag B. Protić's Art-Historical Systematization of 20th-Century Art
}

\author{
Jasmina Čubrilo
}

\begin{abstract}
"Aesthetic contemplation grew into ethical discontent, and ethical discontent into dissatisfaction with the existing view of life, into a feeling of - to use an expression of the Belgrade Surrealists from 1930 - "one constant separation," Fargue's residency in elsewhere, not here, and into the desire to be there instead."
\end{abstract}

Miodrag B. Protić ${ }^{1}$

\section{Introduction}

Miodrag B. Protić (1922-2014) was a prominent figure in the artistic and cultural life of Serbia and Yugoslavia during the 1950s, 1960s and 1970s. His upbringing and intellectual formation were deeply influenced by French culture and modernism; he was a Francophile and a Francophone; a lawyer by education, professionally he was a painter, art critic and theorist of great erudition, with a precise, methodological style of thinking and writing. His public service includes being among the initiators, and then the first director of the Modern Gallery in Belgrade, which later became the Museum of Contemporary Art (MoCAB). With a firm belief in the enlightening and emancipatory power and role of modern art, he consistently defended the (high) modernist ideals of art's autonomy, the universality of experience and understanding of art and the artwork, and the valuation of a work of art exclusively according to "human experience and sensitivity, through an approach immanent to the work", ${ }^{2}$ because, by his thinking, only art that was free and autonomous could be truly progressive, that is, socialist.

Protićs artistic education began when he moved from Vrnjačka Banja to Kraljevo in high school, in drawing classes taught by an Albanian, Vanđel Baduli, who studied under Ljuba Ivanović (18821945) and Ivan Radović (1894-1973) at the Art School of Belgrade and who with his corrections to Protićs first watercolors demonstrated to Protić the modernist postulate "create, don't imitate." In the period before and at the beginning of the Second World War, Protić had the opportunity to meet the Belgrade Surrealists Noje Živanović (1903-1944) and Marko Ristić (1902-1984). Noje’s spouse

1 Miodrag B. PROTIĆ, Nojeva barka. Pogled s kraja veka (1900-1965), Beograd 2000, p. 108.

2 Miodrag B. PROTIĆ, Nojeva barka. Pogled s kraja veka (1965-1995), Beograd 2000, p. 206.

3 PROTIĆ 2000 (n. 1), p. 79. 
Anđa Živanović taught Protić French at the Kraljevo gymnasium, lending him French books on painting from their personal library. Meanwhile Noje, "silent, skinny, tall and stooped", helped Protić select watercolors for his first independent exhibition in the "gymnasium's largest classroom." Marko Ristić spent the first years of the war, from the beginning of 1941 until his arrest in November of 1942, in Vrnjačka Banja, at a sanatorium run by Dr. Dragutin Živadinović, the father of his wife Ševa Ristić; Protić-who at the beginning of the occupation was still living with his parents in Vrnjačka Banja, where he would remain until early January 1943-became, despite his youth, close to the circles in which the Ristićs moved. His departure from Banja to Belgrade was also marked by his acquaintance with the Živadinović family. Dr. Živadinović, one of the most influential people in Serbia in the interwar years and an acquaintance of Protićs father, gave Protić two letters of recommendation: one addressed to his son Vuk, a banker, was meant to secure a job for Protić in Belgrade; the other, addressed to Toma Rosandić (1878-1958), rector of the Academy of Fine Arts, which was located in rented spaces of a house belonging to Marko Ristićs mother's family, was meant to open the doors of the Academy to Protić. The first letter brought Protić a position as a clerk in the Minjon factory in Voždovac, while the second letter went unused. He decided on Mladen Josićs School of Painting, on the top floor of the Kolarac Endowment building, where in 1943 and 1944 Protić was taught by Zora Petrović (1894-1962), Franjo Radočaj (1902-1948), Jovan Bijelić (1884-1964) and Vinko Vitezica (1886-1974) as well as Josić (1897-1972); other students at the time included Radivoj Knežević, Boško Karanović, Ksenija Divjak and Olivera Galović. ${ }^{5}$ In 1945 he joined the Yugoslav People's Liberation War. After the war, he unsuccessfully applied for a scholarship to study law in Paris (upon his father's advice). ${ }^{6} \mathrm{He}$ finally enrolled in the Faculty of Law in Belgrade, graduating in 1950. In the meantime, he continued to paint and show his work at exhibitions organized by the Association of Fine Artists of Serbia, ${ }^{7}$ which he joined in 1948, avoiding the themes of war, revolution and reconstruction, taking instead a modernist approach to the plastic essence of the artwork and the integrity and autonomy of the language of painting. Throughout the 1950s his legal-administrative career was connected to the Ministry of Education, Science and Culture, in which his duties include artwork inspection and, later, head of the department of culture. As Minister of Education, Science and Culture under the government of Petar Stambolić (1951-1953), ${ }^{8}$ Mitra Mitrović showed an understanding for Protićs reports, and likewise for the views promoted by important personages

4 PROTIĆ 2000 (n. 1), pp. 77-78, 90.

5 PROTIĆ 2000 (n. 1), pp. 209-213. Aleksandar Tomašević and Stojan Ćelić, with whom Protić joined Samostalni in 1951, and in 1955 founded Decembarska grupa, studied under Josić in 1942. In 1943 Tomašević received work as a teacher in Badanj in Kopaonik, from which he departed in 1944 for the Ibar Partisan Unit, while Ćelić enrolled in painting school at the Academy of Fine Arts in 1943 and studied under Mihailo Petrov until 1944, when he temporarily interrupted his studies to join the Partisans. See Aleksandar Tomašević (ed. Ljubica Miljković), Galerija Rima, Kragujevac 2010, p. 17; Irina SUBOTIĆ, Ivana SIMEONOVIĆ ĆELIĆ, Stojan Ćelić, Beograd 1996, p. 209.

6 PROTIĆ 2000 (n. 1), p. 259: "You studied (painting) fourteen years, four in grammar school, six in secondary school, two, after that, in Baduli's class before graduating, two after that in Josićs school with Bijelić and Zora. If you're an artist-that is enough; if you aren't-all is in vain. /.../ Study and get your degree in law, and prove that you're an artist, and you'll be an intellectual, not a Balkan bohemian; and if you don't prove it-you'll have as backup a university preparation and a noble vocation. Dr. Živadinović says that his son (Vane Živadinović Bor) and other well-known painters also studied law. And many writers and poets."

7 The Association of Fine Artists in Belgrade was founded in 1919, and was active until the bombing of Belgrade on April 6, 1941; upon the liberation of Belgrade at the end of 1944, it recommenced activities; see Lazar TRIFUNOVIĆ, Srpsko slikarstvo 1900-1950, Beograd 1973, p. 455.

8 Radoš LJUŠIĆ, Ljubodrag DIMIĆ, Ratko MARKOVIĆ, Vlade Srbije. 1805-2005, Beograd 2005, p. 443. 
in the postwar Serbian and Yugoslav art world, such as Milo Milunović, Petar Lubarda, Milan Kašanin and Sreten Stojanović, about the vital need for an institution that would collect, preserve, study and exhibit the modern art that emerged in the territory of Serbia and Yugoslavia, thus reviving an idea from the 1940s about the establishment of the Modern Gallery. ${ }^{9}$ Between 1954 and 1958, when the People's Committee of the City of Belgrade founded the Modern Gallery, Protić, with concealed or open support from the ministry, formally as its employee, and by conviction as a painter and art critic, made a number of strategic moves: on the one hand, these goals were intended to revoke plans for upgrades to the Mortgage Bank, into which the National Museum had moved with purpose of exhibiting 20th-century art from its collection (including surveys of prominent artists, critics, historians, professors from the Faculty of Philosophy in Belgrade and the Association of Fine Artists of Serbia on the necessity of the Modern Gallery as an independent institution; negotiations with the directors of the National Museum in 1954), and, on the other hand, to continue with the establishment of the Modern Gallery (including the selection of the gallery's founding committee in 1955, charged with the task of determining its programming and structure according to national and international experience). ${ }^{10}$ Finally, in 1959, at the end of the decade, one year after the formation of the Modern Gallery, Protić is named its director, which meant leaving, or rather transferring his job to the minister Aleksa Čelebonović.

Simultaneously to his tenure at the ministry, in the 1950s Protić continued to develop his painting career, resulting in important shows, the most significant of which were the 2nd Tokyo Biennale in 1955 with Petar Lubarda, Oton Gliha, Marko Čelebonović and Edo Murtić; his first solo exhibition at the Art Pavilion in Belgrade in 1956; and exhibitions at the 28th Venice Biennale in the Yugoslav Pavilion together with Vojin Bakić, Marij Pregelj and Lazar Vujaklija, for which he received the UNESCO award. For the latter two shows he also received the City of Belgrade's October Award, at the time a highly prestigious prize. As a painter and critic, he actively participated in the postsocialist realism reorganization of the art world in Serbia and Yugoslavia, and in the determined promulgation of the ideas and language of modern art. For example, during a debate between two factions of the Association of Fine Artists of Serbia that culminated in 1951 when a small group of artists-prewar modernists opposed to the association's dogmatic politics that were supported by the majority of its members, and in particular the arbitrary direction concerning creative-artistic issues-breaks off and organizes itself as Samostalni (Independents), Protić and his generation supported them. Likewise, as a founder and active member of Decembarska grupa (December

9 In 1948 there was a competition for the building of the Modern Gallery on the left bank of the Sava River according to Nikola Dobrovićs urban plan articulated in 1946 in the draft regulation of New Belgrade on the left bank of the Sava. Nevertheless, despite the prizes being distributed-first place went to architects Edvard Ravnikar and Veljko Kauzlarić, second place to architect Branko Petričić—-the project was never realized; see Ljiljana BLAGOJEVIĆ, Novi Beograd. Osporeni modernizam, Beograd 2007, pp. 60-72, 220; http://www.citajteo.rs/indexmuzej-savremene-umetnosti.php (accessed: 12 March 2017).

10 The committee was comprised of Stanka Veselinov (sociopolitical worker of the Federal People's Republic of Yugoslavia and the successive Socialist Federal Republic of Yugoslavia) as committee president; Miodrag B. Protić secretary; Veljko Petrović (a writer and at the time director of the National Museum); Oto Bihalji Merin; Milo Milunović (painter), who left due to other obligations; Đorđe Andrejević Kun (painter); Svetozar Radojčić; Predrag Milosavljević (painter); Stevan Bodnarov (sculptor); Dobrica Ćosić (writer); Vlado Mađarić (conservator); and Aleksa Čelebonović (painter, art critic, and at that time founder of the Yugoslav section of the International Association of Art Critics and commissioner of the Yugoslav selection at the Biennale in Venice in 1957 and in São Paolo in 1958). All the members of the committee were from Serbia except Mađarić, who was from Croatia; see Muzej savremene umetnosti (ed. Miodrag B. Protić), Muzej savremene umetnosti, Beograd 1965, p. 18. 
Group, 1955-1960), he continued to promote modernist ideas about an artwork/painting as a system organized according to its own rules. As Protić was of the opinion that "in 1951 art historians could not write criticism because they knew nothing of artistic practice and had not yet studied the philosophy of modern art," he accepted the challenge, as he pointed out, of the tradition of the artistcritic, intensified in the Serbian milieu (Nadežda Petrović, Moša Pijade, Petar Dobrović, Aleksa Čelebonović), ${ }^{11}$ and began to write art criticism for $L i k$, newspaper of the Association of Fine Artists of Serbia, for Nedeljne informativne novine [Weekly Informative News], whose circulation recommenced in 1951, and for Delo [Work], in which he entered into a debate with Grgo Gamulin and also a wider polemic on the relationship between modernism and realism led by Delo and the magazine Savremenik [Contemporary]. In 1955 he published his first book under the title Savremenici. Likovne kritike i eseji [Contemporaries. Art Criticism and Essays], ${ }^{12}$ which, although organized as a collection of Protićs art criticism and essays on "artists of continuity"- in other words, a collection of monographic units-nevertheless anticipates, in a methodological and interpretive sense, the future systematization of modern art in Serbia and Yugoslavia. ${ }^{13}$ Finally, he spent the period from November 1953 until February 1954 in France on a Serbian governmental scholarship for professional and artistic development, and then on a scholarship from the French government in 1957.

In the early 1960s Protić was occupied above all with resolving key issues related to the Modern Gallery: the building, collaborators and collection. The offices of the Modern Gallery were from the outset located in the loft of 5 Obilićev Venac in an old part of Belgrade. At the end of 1959, a competition for the preliminary design of the Modern Gallery was held, and he received the entries by the end of January the next year (fig. 1). The architects Ivan Antić and Ivanka Raspopović won first place with their design, according to which the Executive Council of Serbia, as investor, began construction on the left bank of the Sava River, in the New Belgrade district, ${ }^{14}$ near the building of what was then the Central Committee of the League of Communists of Yugoslavia (today's Ušce Tower). At the beginning of May 1961, on the ground floor of a building by architect Miroslav Mirko Jovanović at 15 Pariska Street in the old town, in close proximity to the Academy of Fine Arts (now the Faculty of Fine Arts), the Salon of the Modern Gallery was opened (after 1965, the Salon of the MoCAB) ${ }^{15}$ with the intention of exhibiting contemporary, that is current, trends in art not only in Yugoslavia but the

11 PROTIĆ 2000 (n. 1), pp. 348-349.

12 Miodrag B. PROTIĆ, Savremenici. Likovne kritike i eseji, Beograd 1955.

13 It deals with the artists whose works were represented in the exhibition Seventeen Works of Painting and Sculpture, 1920-1940, held at the beginning of 1951 in the Gallery of the Association of Fine Artists of Serbia in Belgrade. This exhibition did not bear a national mark; because works were shown by artists who at the time lived and worked in Belgrade, regardless of their origins (Vinko Grdan), or artists who did not live in Belgrade but who actively collaborated with colleagues and institutions in Belgrade (Marino Tartaglia), and likewise because Belgrade was the administrative center of the Federal People's Republic of Yugoslavia, one could conclude that if the exhibition had any character at all, it was a Yugoslav one.

14 In his memoirs Protić notes that despite his efforts he did not realize his intentions that the Modern Gallery moves into the new building in the old part of Belgrade, and that he consented to the New Belgrade location because one politician told him in confidence: “Today you're losing time, tomorrow you could lose the Gallery, too!"; see PROTIĆ 2000 (n. 1), p. 513.

15 The newly erected building was intended as a residence and workplace for prominent artists and cultural workers and their families. Among the first to live here were Ivan Tabaković, Stojan Aralica, Milenko Šerban, Ivan Radović, Predrag Peđa Milosavljević, architect Miroslav Mirko Jovanović and Živojin Zdravković, conductor and director of the Belgrade Philharmonic and professor at the Academy of Music. More on this subject: Irina SUBOTIĆ, Salon Muzeja savremene umetnosti. Prve decenije, Prilozi za istorizaciju Muzeja savremene umetnosti (ed. Dejan Sretenović), Beograd 2016, p. 178. 


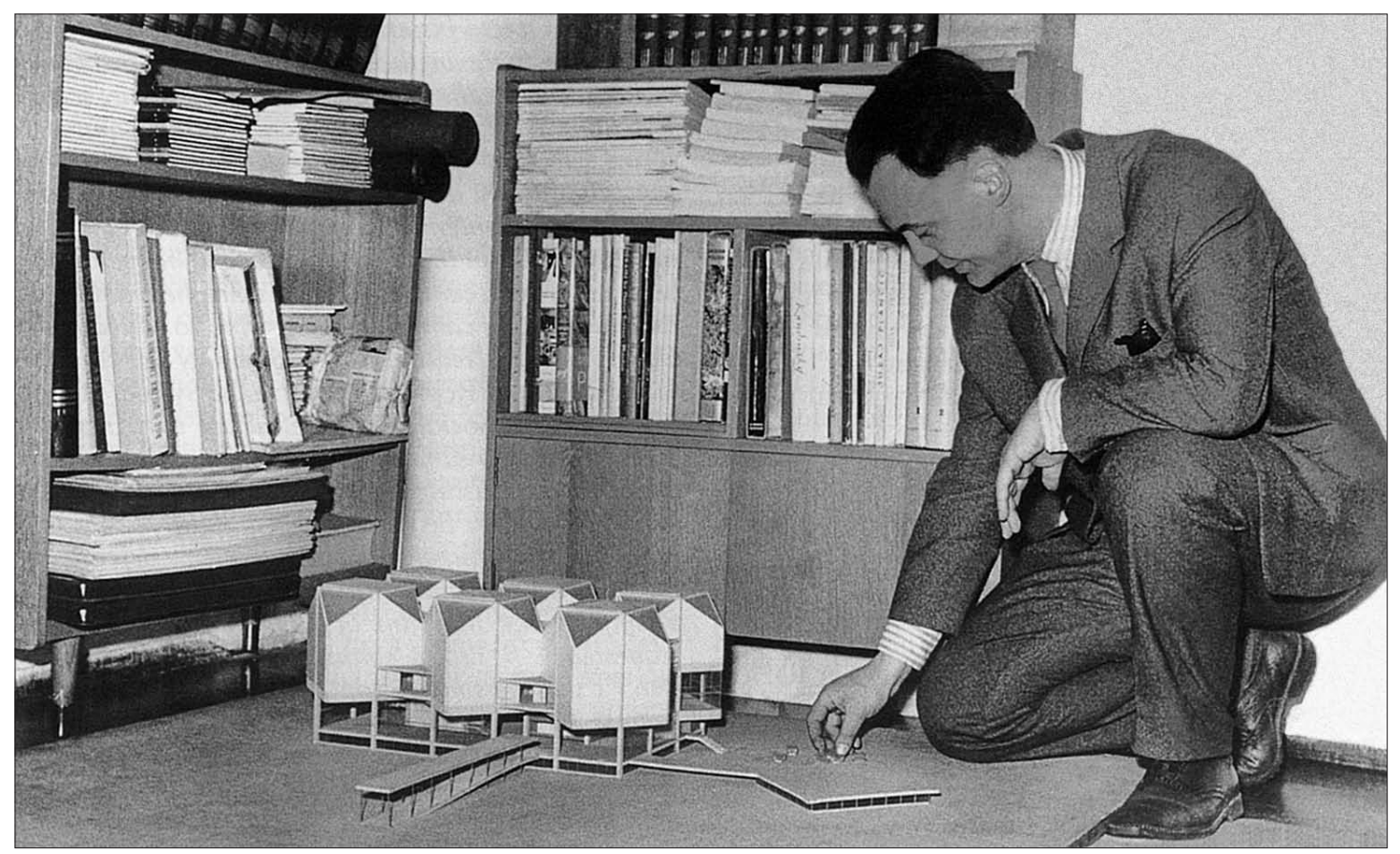

1. Miodrag B. Protic in the office of the Modern Gallery in Belgrade with the model of the Museum of Contemporary Art (MoCAB), c. 1960

world. It was Belgrade's first "gallery with a modern conception", ${ }^{16}$ with carefully prepared catalogues featuring an introduction, reproductions, a biography of the artist, a bibliography and all the details about the works displayed. In terms of collaborators in his new institution (the Modern Gallery and Salon), Protić wanted "new, young people" (he engaged, for example, Dragoslav Đorđević, Božica Ćosić, Jerko Ješa Denegri, Irina Subotić) who would develop professionally "alongside him and the selected program". ${ }^{17}$ Finally, the question of what would constitute the future museum's foundation was equated with the creation of "the most complete and most valuable collection of Serbian and Yugoslav art of the 20th century," ${ }^{18}$ with a search for the right material, "works through which the main task of the Museum would be realized: the most convincing and objective visualization of all protagonists, epochs and poetics, Serbian and Yugoslav, of the 20th century". ${ }^{19}$ It was not just a matter of the accessibility of the works and their prices, but also of the vertical structuring of the experience of 20thcentury art from the territory of Yugoslavia and its representation-in other words the performative potential of the selection, the argumentation and interpretation of which would realize a coherent narrative history of modern art. In that regard, Protićs travel to America in 1963, on a research grant from the Ford Foundation, represents a highly significant moment for this projected goal. Meeting with Alfred H. Barr Jr., René d'Harnoncourt and the architect Philip Johnson, Protić gained an understanding of the ideological, structural, organizational and methodological principles of the Museum of Modern Art (MoMA), using this to shape his vision of the MoCAB as a space for the articulation of

\footnotetext{
6 SUBOTIĆ 2016 (n. 15), p. 175.

17 PROTIĆ 2000 (n. 1), p. 514.

18 PROTIĆ 2000 (n. 1), p. 515.

19 PROTIĆ 2000 (n. 1), p. 514.
} 


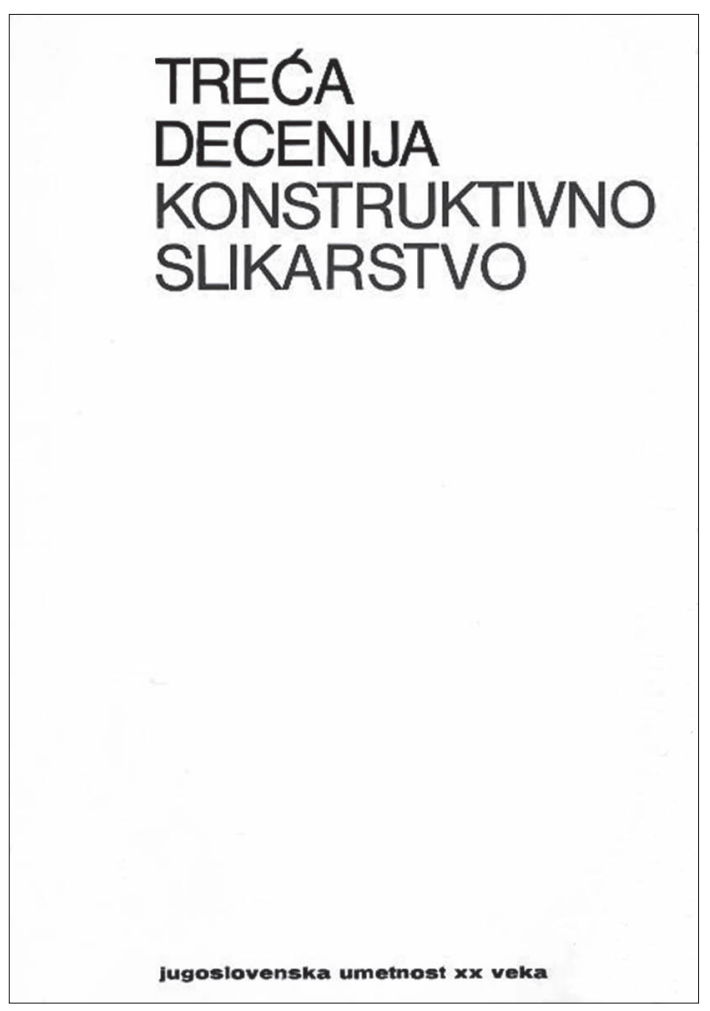

2. Treća decenija. Konstruktivno slikarstvo (ed. Miodrag B. Protić), Beograd 1967, book cover

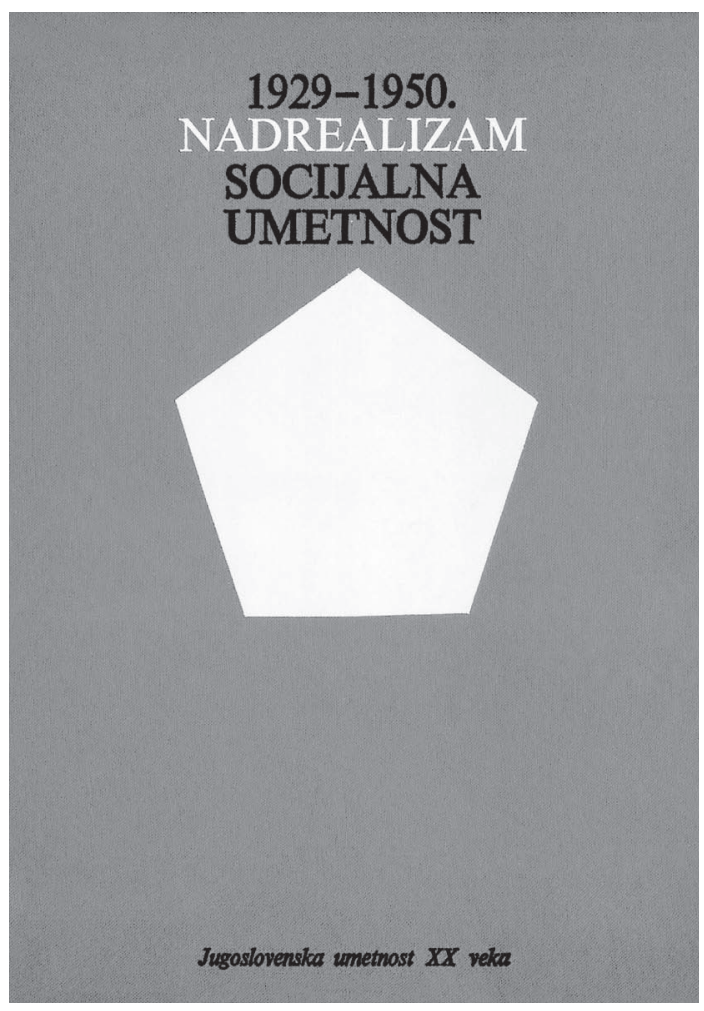

3. Nadrealizam, socijalna umetnost

(ed. Miodrag B. Protić), Beograd 1969, book cover

knowledge about Serbian/Yugoslav/international modern art. Two years after the MoCAB's opening, Protić initiates the book series Jugoslovenska umetnost XX veka [Yugoslav Art of the 20th Century]. The first volume, published in 1967, was Treća decenija. Konstruktivno slikarstvo [The 1920s. Constructivist Painting] (fig. 2), then followed Nadrealizam, socijalna umetnost. 1929-1950 [Surrealism and Social Art. 1929-1950] in 1969 (fig. 3); Četvrta decenija. Ekspresionizam boje, poetski realizam [The 1930s. Expressionism of Color and Poetic Realism] in 1971 (fig. 4); Počeci jugoslovenskog modernog slikarstva. 1900-1920 [Beginnings of Yugoslav Modern Painting. 1900-1920] in 1972; Jugoslovenska skulptura 1870-1950 [Yugoslav Sculpture 1870-1950] in 1975; Jugoslovensko slikarstvo šeste decenije [Yugoslav Painting of the 1950s] in 1980; and finally, after Protićs retirement but conceived in the same way Jugoslovenska grafika 1950-1980 [Yugoslav Graphic Art, 1950-1980]. ${ }^{20}$ Protić's art criticism grows into art-history writing and then gives way to editing books, but also to a major synthesis

20 Treća decenija. Konstruktivno slikarstvo (ed. Miodrag B. Protić), Muzej savremene umetnosti, Beograd 1967 (Jugoslovenska umetnost XX veka); Nadrealizam, postnadrealizam, socijalna umetnost, umetnost NOR-a, socijalistički realizam. 1929-1950 (ed. Miodrag B. Protić), Muzej savremene umetnosti, Beograd 1969 (Jugoslovenska umetnost XX veka); Četvrta decenija. Ekspresionizam boje, kolorizam, poetski realizam, intimizam, koloristički realizam (ed. Miodrag B. Protić), Muzej savremene umetnosti, Beograd 1971 (Jugoslovenska umetnost XX veka); Počeci jugoslovenskog modernog slikarstva. Plenerizam, secesija, simbolizam, minhenski krug, impresionizam, ekspresionizam. 1900-1920 (ed. Miodrag B. Protić), Muzej savremene umetnosti, Beograd 1972 (Jugoslovenska umetnost XX veka); Jugoslovenska skulptura 1870-1950 (ed. Miodrag B. Protić), Muzej savremene umetnosti, Beograd 1975 (Jugoslovenska umetnost XX veka); Jugoslovensko slikarstvo šeste decenije (ed. Miodrag B. Protić), Muzej savremene umetnosti, Beograd 1980 (Jugoslovenska umetnost XX veka); Jugoslovenska grafika 1950-1980 (eds. Kosta Bogdanović, Ješa Denegri), Beograd 1986 (Jugoslovenska umetnost XX veka). 


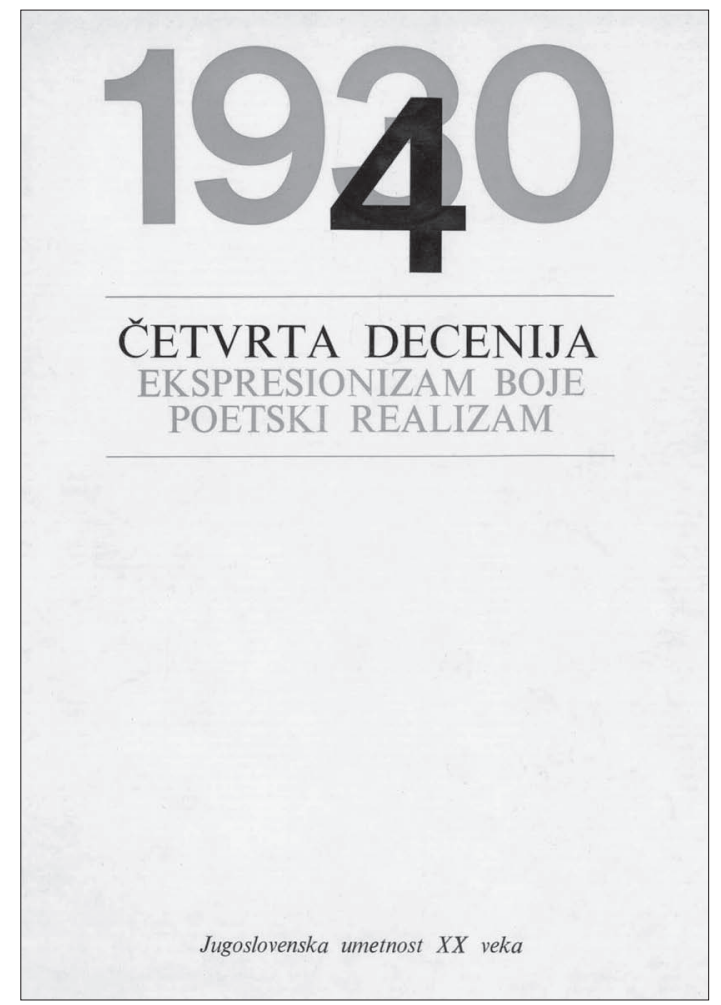

4. Četvrta decenija. Ekspresionizam boje, poetski realizam (ed. Miodrag. B. Protić), Beograd 1971, book cover

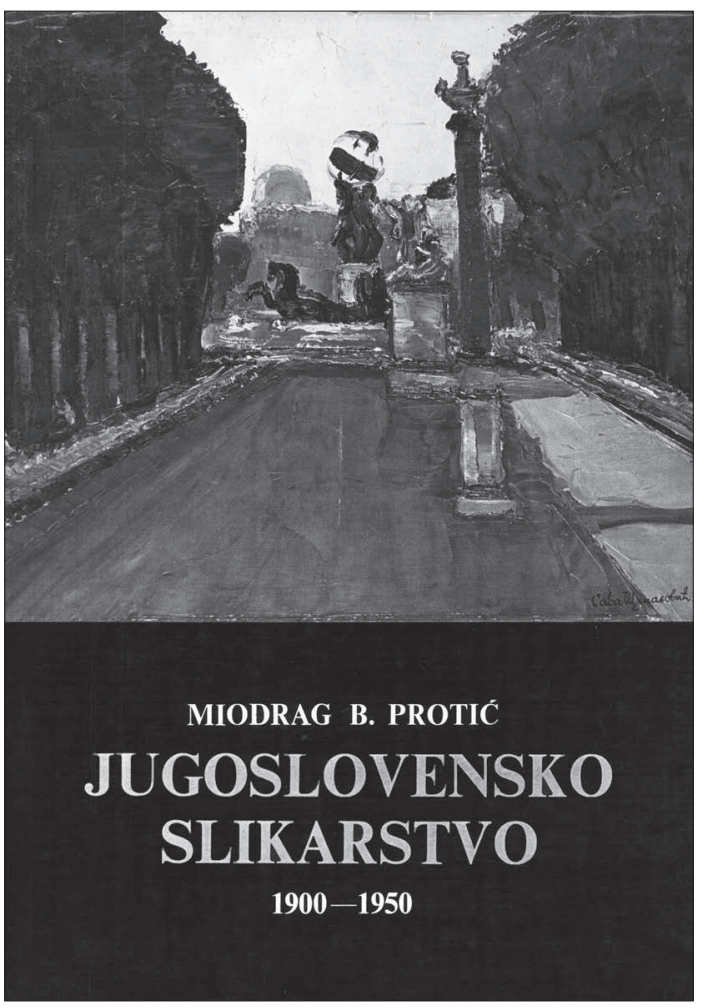

5. Miodrag B. Protić, Jugoslovensko slikarstvo 1900-1950, Beograd 1973, book cover

of 20th-century Serbian art published in $1970^{21}$ - as well as a survey Jugoslovensko slikarstvo [Yugoslav Painting], published in 1973, which he defined as "a study—a sketch of one possible synthesis of Yugoslav art of the first half of the 20th century" (fig. 5). ${ }^{22}$

On the other hand, in the 1960s Protić painted actively and exhibited his work in Yugoslavia and beyond (for example, in overview exhibitions of Yugoslav Art at London's Tate Gallery in 1961, at the Museum of Modern Art in Paris at the end of 1961 and beginning of 1962, and with Gabrijel Stupica, Dušan Džamonja, Janez Bernik and Vjenceslav Rihter at the Eighth Biennial in São Paolo in 1965), and received awards at the First Triennial of Yugoslav Art in 1961, and in Rimini at the third exhibition of the Premio Morgan's Paint. His artistic work entered overviews of contemporary art, such as Raymond Bayer's L'esthétique mondiale au XX⿳亠丷 siecle (1961) or, later, Ultime tendenze nell'arte d'oggi (1974) by Gillo Dorfles.

He became a corresponding member of the Yugoslav Academy of Sciences and Arts in Zagreb in 1966 with the painters Milo Milunović, Stojan Aralica and Petar Lubarda. ${ }^{23}$

21 See Miodrag B. PROTIĆ, Srpsko slikarstvo XX veka, 1-2, Beograd 1970. Lazar Trifunović, in his doctoral dissertation Serbian Painting in the First Half of the 20th Century (1900-1950), defended in 1960 at the Philosophical Faculty of the University of Belgrade, undertook a pioneering project of art-history systematization and interpretation, though the wider public were only to become acquainted with the findings of his research in 1973, when Nolit in Belgrade publishes Trifunović’s book; see TRIFUNOVIĆ 1973 (n. 7)

22 Miodrag B. PROTIĆ, Jugoslovensko slikarstvo 1900-1950, Beograd 1973, p. 7.

23 For the conditions under which Protić was nominated to be a corresponding member of the Serbian Academy 


\section{Toponym or Ideology: the Trouble with an Adjective}

In his art criticism and theoretical texts, as well as in his own painting, Protić tirelessly presented a belief in art's autonomy, in the universal language of formal properties of art, and hence of the universality of the experience and understanding of a work of art. Protićs critical and theoretical horizons, although shaped by the critical reception of the ideas of Lionello Venturi, Henri Focillon, Giulio Argan, Herbert Read, Clive Bell, Roger Fry and Thomas Munro, was ideologically very close to the paradigms of modernist art whose formulation is attributed to Theodor Adorno and Clement Greenberg, and which defines modernist art as experimental, innovative and autonomous creation by a subjective and rational individual. Its essence is to:

/.../ remind man how much the world is beyond his control and estranged from him, and to call on him to change; and secondly to calm man and replace that which his life has truncated, offering refuge, making possible his unification with the world, nature, as well as dialogue with the "other". ${ }^{24}$

Modern and contemporary art is, according to his thinking, authentically modern/contemporary insofar as it possesses an international character and emancipatory potential, whereby he took international to mean the framework or even a condition for the realization of the emancipatory process. In permanent and thematic displays that focused on the work of art rather than the artist, and which were realized as a "chronological succession of poetic sequences" for the sake of the best possible uncovering and understanding of the epoch and its representatives, ${ }^{25}$ the adjective "Yugoslav" referred to, on the one hand, the political idea of the Yugoslav people, which was shared by intellectuals at the turn of the 20th century, while on the other hand, it referred also to the governmental-territorial whole formed in 1918, which over the course of the 20th century was reorganized multiple times, along with its ideological-political constructs that produced positions of identity as well as the cultural and artistic space.

The year 1900, which Protić in the titles of his editions identifies as the chronological beginning of Yugoslav modern art, remains questionable. Other than the fact that it marks the beginning of the 20th century, nothing happened in 1900 that could be interpreted as pivotal to the formation and representation of the idea of Yugoslav art, such as, for example, the Yugoslav Art Exhibitions (the first was held in 1904, the last in 1927), which were meant to confirm the idea of the Yugoslav cultural and artistic community as an individual cultural entity facing or in the relation to other European peoples and cultures-a community that, while not entirely homogenous, nevertheless shared enough similar or even identical characteristics that make it possible to consider it a whole. ${ }^{26}$ From Protićs texts, one has the impression that he in fact chose 1900 in a very conventional sense, and that he is speaking more of the time around 1900, when the processes of movement away from 19th-century tradition and academicism toward Impressionism and Pleinairism, Symbolism and Secession were

of Sciences and Arts in 1967, and on the course of the negative outcome of the vote, see PROTIĆ 2000 (n. 2), pp. 17-19.

24 Miodrag PROTIĆ, Iskaz autora, Poetika i simboli Miodraga B. Protića (ed. Svetlana Jovanović), Muzej savremene umetnosti, Beograd 2006, p. 15.

25 Miodrag B. Protić (ed. Radmila Matić-Panić), Beograd 1983, p. 33; reprinted in: Prilozi 2016 (n. 15), p. 70.

26 TRIFUNOVIĆ 1973 (n. 7), p. 449. 
underway, and if a year must be chosen as the beginning of Yugoslav modern art, then it is, according to Protić, most certainly 1904 and the First Yugoslav Art Exhibition. ${ }^{27}$ On the other hand, 1900 as a zero year is legitimized by national historiographies that recognize in events such as participation in the World Exhibition in Paris ${ }^{28}$ and the Slovenian Art Exhibition ${ }^{29}$ symbolic moments indicating the emergence of modern tendencies in art or the separation of the modern from the traditional and academicism, and to which one could, in the discourse on Yugoslavism, ascribe the potential for anticipation of supranational artistic collaboration and an emerging cultural community, such as the Second Exhibition of Croatian Artists, which, in addition to showing the work of Menci Clement Crnčić and Alfons Mucha, also exhibited works from the just-concluded Slovenian Art Exhibition as a third segment. ${ }^{30}$

Likewise, one notices both in Protićs editing of the series Yugoslav Art of the 20th Century and in his book on Yugoslav Painting between 1900 and 1950 that the adjective Yugoslav more closely determines/defines (modern) art and not the history of that art, which can be understood as the approach of a critic (and artist) who is systematizing poetic entities organized, indeed, into regular chronological entities-decades-and perhaps as the expression of a certain caution due to the complex rhetoric of Yugoslavism.

The first question to be asked is whether we can identify the chronological and problem-oriented connection and systematization of "poetic entities" as the formation of an art-historical text/ narrative. Protićs approach was based on a theoretical analysis and examination of the origin of the work of art, on a consideration of the work of art as one of the possible manifestations of a certain wider abstract structure. The point of departure for his theoretical, critical and/or historical interpretations of the work of art is grounded in Protićs direct experience and the belief of a modernist painter that the poetic aspects of an artwork are immanent to it, integrated into the approach towards its creation and in the work itself. His interpretations were oriented toward the identification, description and explanation of artistic facts as aesthetic, and then toward the observation and interpretation of their relation to conceptualized, historically differentiated "families" of similar works of art on the one hand, and the recognition, description and explanation of artistic facts in relation to the social, cultural and historical context in which they emerge, on the other. The diachronic structure (inside of which Protić, in fact, holding to pluralism as a basic

27 Miodrag B. PROTIĆ, Počeci jugoslovenskog modernog slikarstva, Počeci 1972 (n. 20), pp. 7-22.

28 TRIFUNOVIĆ 1973 (n. 7), pp. 11-12, 15, 448-449. For a more detailed critical analysis of the meaning of this exhibition in the historiography, but above all of its significance in the cultural history of Serbia, see Simona ČUPIĆ, Teme i ideje modernog. Srpsko slikarstvo 1900-1941, Novi Sad 2008, pp. 12-13, 19-28.

29 Among the thirty or so artists featured at the First Slovenian Exhibition, the works of four-Ivan Grohar, Matija Jama, Matej Sternen and Rihard Jakopič_as those evidencing a tendency toward a modernist sensibility and manner of expressing that sensibility make this exhibition and year the symbolic beginning of modern Slovenian art; see Špelca ČOPIČ, Počeci slovenačkog modernog slikarstva, Počeci 1972 (n. 20), pp. 48-49, 190.

30 See Druga izložba Društva hrvatskih umjetnika u Umjetničkom paviljonu u Zagrebu, Umjetnički paviljon, Zagreb 1900. In the historiography of modern art in Croatia, the year 1898 marks the beginning of the period when the First Croatian Salon was held in the Art Pavilion in Zagreb, which presented to the public works of the group of artists gathered around new, anti-traditional ideas, artists who a year earlier, led by Vlaho Bukovac, had separated from the Society of Artists (whose program during the 19th century was shaped by Izidor Kršnjavi) and founded the Society of Croatian Artists. See Božidar GARGO, Putevi modernosti u hrvatskom slikarstvu, Počeci 1972 (n. 20), pp. 34-35, 189-190; Ivanka REBERSKI, Rađanje hrvatske moderne 1898. godine, Hrvatski salon 1898. 100 godina Umjetničkog paviljona (ed. Lea Ukrainčik), Umjetnički paviljon, Zagreb 1998, p. 13; Petar PRELOG, Artikulacije moderniteta. Institucije, secesije, publika, Moderna umjetnost u Hrvatskoj, 1898.-1975. (eds. Ljiljana Kolešnik, Petar Prelog), Zagreb 2012, pp. 11-18. 
principle, actually perceives phenomena synchronically) in Protićs speculative connections between pictorial formalist analysis and theoretical languages (existentialism, structuralism, phenomenology) also implies an intention to interpret art in a given time period and spatial/territorial frameworks and the cultural-historical contexts that belong to them. In other words, he deconstructs criticaltheoretical writing about "poetic sequences" in an attempt or an initial move or a sketch or a proposal of an art-historical narrative:

Innovation and the efforts of research /.../ of the cycles of 20th-century Yugoslav art /.../ it is not only according to that /.../ the selection of the works of one artist or another, but above all in the way they connect to stylistic sequences and the many stylistic sequences in the periods and epochs. /.../ Established poetic sequences lead to /.../ periodization /.../: if stylistic sequences are constituted by the selection of works, periods are constituted by stylistic sequences. ${ }^{31}$

The conspicuous absence of a designation of the discipline in which the frameworks are described, analyzed and interpreted, and the studied phenomena and concepts then systematized, does not imply disciplinary uncertainty or indecision, but rather can be interpreted as a result of the assumption of a scientific-theoretical framework for the study of art, an assumption that arises from a high esteem towards the object of study.

On the other hand, Protić's (enlightened, modernist) unquestioning belief in the neutrality and objectivity of theoretical approaches and scientific disciplines-due to which their anational character is postulated, or, more precisely, on the basis of which it is assumed that they make a national contribution to Science, which belongs to everyone-poses the question whether it makes any sense to ask whose history of art can be spoken of. Likewise, if the object of description and study were Yugoslav modern art and if its study were consistently realized from the position of a formalanalytic, historiographical and comparative approach, would it then be logical to assume that this is a matter of a methodologically based, coherent narrative of the Yugoslav history of modern art? In the content of his series Yugoslav Art of the 20th Century, Protić implicitly announces such a narrative; at the same time, however, through the structure of the series he calls it into question, if not negating it: each edition of Yugoslav Art of the 20th Century is divided into individual presentations of the art of the old (prewar)/new (after the Second World War) Yugoslav cultural and artistic centers, and colleagues from related institutions in those centers were engaged as authors of review articles. In other words, the structure of each publication in the series repeated and reflected the political function of the federal state on the principle of the equal presentation of each republic. Does such an approach by Protić indicate the political insecurity of a public servant, who then decided to take a position compatible with the state-political order? Or was this approach a sign of an authentic respect for different identities rooted in their respective traditions, although in the framework of which it was simultaneously permitted to postulate, through the observation and mapping of their shared interconnections and influences that transcended the given identities, some new identity that would promulgate the idea of internationalism, or at least an established new tradition in socialism? How to understand "Yugoslav" in the syntagm Yugoslav art of the 20th century-as a toponym and/ or as an effect of the discourse on Yugoslavism, i.e. as an ideological construct?

31 Miodrag B. PROTIĆ, Odnos predmeta i metoda, Jugoslovenska skulptura 1975 (n. 20), p. 13. 
Examination of the adjective Yugoslav's meaning in the syntagm Yugoslav art encompasses questions of the origins of the relationship between the Yugoslav idea and art, and then of the meaningful relations of ideologies/concepts of Yugoslavism and culture and art that developed within the discursive and material borders of Yugoslavia, and, finally, the meanings assigned or produced by Protić's use, initiated by the conception and programming of the work of the museum, the goals and tasks of which were determined as:

the collection of the best and most characteristic works of contemporary Yugoslav art; constant cooperation between republics; intensive international cooperation-the inclusion of our art in world art and representation of world art in our milieu; affiliations (traveling exhibitions, lectures, cooperation with schools, etc.); and the cultural-historical, sociological, aesthetic and comparative study of Yugoslav art of the 20th century. ${ }^{32}$

As we have seen, Protić viewed the beginnings of Yugoslav modern art in artistic phenomena whose modernity he interpreted not only from the perspective of formal problems and research, but also as a manifestation of the artist's ideological-political position, represented by the organization of the First Yugoslav Art Exhibition in 1904 and the exhibition of the Yugoslav artist colony in 1907. ${ }^{33}$ Paradoxically, upon creation of the unified state, the idea of an integrated Yugoslavism-one of the substantial ideas for the political conceptualization and formation of the new state, as well as for the legitimization of its centralist order and unified system of rule (particularly after 1929 and the establishment of the Kingdom of Yugoslavia) - ceases to be relevant among artists of the new generation in the way it was for the leading circle of artists of the previous generation. The reasons for this distancing from, or abandonment of, the idea of an integral Yugoslavism in the field of art in historiography are recognized in efforts directed towards the affirmation of the autonomy of modern $\mathrm{art}^{34}$ and the development of a contemporary supranational expression (the results of the influence of the Paris School's international character, which produced paradigmatic, universal, anational models of modernism), as well as in new forms of collaboration between artists from different centers of the new state, focused mainly on affirming and institutionalizing the universal language of "form and color," and the fundamental marginalization of "the anecdote, history". ${ }^{35}$ After the First World War, the unified state became for artists primarily a geographical reality of wider cultural heterogeneity. This enabled broader, simultaneous, nomadic, and even strategically conceived, larger, more efficient representations of modernist ideas in art through exhibition activity, the joint work of artists, artistic-educational work, journal publication and the development of art criticism and theory. Careful study of the typology of the scene (which completely aligns with the narrative matrix of the epoch) even points to ideological-political disputes, re-examinations to the

32 Miodrag B. PROTIĆ, Uvod, Treća decenija 1967 (n. 20), p. 4.

33 The exhibition of the Yugoslav artist colony was the result of disagreement, misunderstandings and factionalizing among artists after the First Yugoslav Art Exhibition, conditioned by various ideological positions: integral Yugoslavism supported by Nadežda Petrović, Ivan Meštrović, Paško Vučetić, Rihard Jakopič, Emanuel Vidović, Ferdo Vesel and Ivan Grohar in opposition to Yugoslav nationalism and even minimal Yugoslavism, supported by artists who formed the Lada Society.

34 See Aleksandar IGNJATOVIĆ, Između politike i kulture. Integralno jugoslovenstvo i likovna umetnost, Zbornik Seminara za studije moderne umetnosti Filozofskog fakulteta Univerziteta u Beogradu, 6, 2010, p. 15.

35 See Ana BOGDANOVIĆ, Umetničke veze između Beograda i Zagreba na primeru saradnje između Grupe umetnika i Proljetnog salona (1919-1921), Zbornik Narodnog muzeja, 21/2, 2014, p. 284. 
point of self-criticism of the multinational kingdom's national identities, just as it shows that in fact "anecdote, description" are actually still relevant as elements of the individual peculiarities of national modernisms. ${ }^{36} \mathrm{Up}$ until the beginning of the Second World War two more ideas could be mapped: the first was the idea of the Barbarogenius, a radical reconceptualization of the asymmetrical cultural relationship and politics of the identities of Europe and the Balkans in which a raw, authentic, pagan, fresh, healthy, Slavic, or more precisely Balkan energy and spirit was attributed with the power to reinvigorate and renew Europe's withered, decadent and compromised culture and art, and which Micić fiercely proselytized in the context of Zenitism; and the second, which put the question of class and identity before the national question (social art). Finally, in the period after the Second World War, one can speak of several approaches: on the one hand there was the idealistic and official, which emerges from the revolutionary heritage and which refers to Yugoslav identity not as something national but rather as a modality, almost a class epithet, ${ }^{37}$ and on the other hand there is the practical approach, determined by the political and economic decentralization of the state at the beginning of the 1960s. Even a cursory and completely random glance at the large number of exhibitions whose goal was to present Yugoslav art (and culture) abroad from the beginning of the 1950s-whether carefully planned survey shows that aimed above all to affirm the Yugoslav sociopolitical concept and process of the liberalization of cultural politics, or whether collective or independent shows by artists from socialist Yugoslavia in major international exhibitions (such as the biennales in Venice and São Paolo)-demonstrates that these two approaches, Yugoslav conceptualized as an anational class epithet and Yugoslav conceptualized as a collection of balanced representations of the federal (national) contexts, structured these presentations. On the other hand, judging by the numerous artistic (and other cultural) manifestations that were initiated in the 1960s, and which had a distinctly Yugoslav character (such as the Memorial for Nadežda Petrović in Čačak, the Autumn of Art in Sombor, the Triennial of Yugoslav Art in Belgrade, the Biennale of Young Yugoslav Artists in Rijeka and the Biennale of Yugoslav Graphic Art in Zagreb), one could say that the political powers endeavored to compensate for the effects of the institutional reorganization of space and discourse of Yugoslav federal socialism with the idea of Yugoslavism..$^{38}$ Likewise, a range of texts by critics and art historians from different Yugoslav centers that refer to Yugoslav art attests

36 See Ivanka REBERSKI, Realizmi dvadesetih godina. Magično, klasično, objektivno u hrvatskom slikarstvu, Zagreb 1997, pp. 25-28; Igor KRANJC, Modernizem v obdobju diktature, Umetnost tridesetih let iz zbirk Moderne galerije Ljubljana. Prvi študijski zvezek. 1928-1934 (ed. Igor Kranjc), Moderna galerija, Ljubljana 2004, pp. 4-29; Igor KRANJC, Umetnost v navzkrižjih utilitarnih nazorov, Umetnost tridesetih let iz zbirk Moderne galerije Ljubljana. Drugi študijski zvezek. 1935-1937 (ed. Igor Kranjc), Moderna galerija, Ljubljana 2006, pp. 5-18; ČUPIĆ 2008 (n. 28); Petar PRELOG, Problemi samoprikazivanja. Umjetnost i nacionalni identitet u međuratnom razdoblju, Moderna umjetnost 2012 (n. 30), pp. 236-257; Asta VREČKO, Vzpostavljanje nacionalnega izraza v delovanju Kluba neodvisnih slovenskih likovnih umetnikov, Ars \& Humanitas. Revija za umetnost in humanistiko, 9/2, 2015, pp. 84-105; Asta VREČKO, In Search of the National. Slovenian Art in the 1930s, Art and its Responses to Changes in Society, Newcastle upon Tyne 2016, pp. 130-151.

37 Dejan JOVIĆ, Jugoslavija - država koja je odumrla. Uspon, kriza i pad Četvrte Jugoslavije (1974-1990), Beograd 2003, pp. 37-58; 119-154.

38 Ješa Denegri interprets the numerous exhibitions of a Yugoslav character and grouping of participants (even if that character was not announced in the exhibition title) that were organized throughout the existence of the unified state in its various cities, such as Zadar, Dubrovnik, Zrenjanin, Zenica, Banja Luka, Tuzla and Slovenj Gradec (in addition to the aforementioned), as a move that contributed to the "demetropolization of the Yugoslav cultural space”; see Ješa DENEGRI, Ideologija postavke Muzeja savremene umetnosti. Jugoslovenski umetnički prostor, Beograd 2011, pp. 18-19. 
to the fact that Protić was not the only one to use this syntagm. ${ }^{39}$

The concept and structure of Protićs series on Yugoslav 20th century art, as well as of his book on Yugoslav painting between 1900 and 1950, are based on his respect and acceptance of a pluralism of statements and his firm belief in the emancipatory potential of the international language of art. The use of the adjective Yugoslav refers to the geographic entity and to the framework of the statepolitical identity within the context of which ethnic cultures exist and develop, functioning without interference and cooperating amongst each other. For Protić, Yugoslav, besides referring to a pluricentral cultural and artistic space, also refers to one stage in the dialectical movement from the particular and local to the universal and international. In that movement, in which the local/ethnic is generalized through the language of art and form into the plural Yugoslav, respectively into the international, in the process changing and contributing to the enrichment and constructive development of both the Yugoslav/supranational and international alike, Protić saw a liberating potential for all involved in those processes: just as the local is emancipated by internationalization, so the international, through the modifying effects of recognizing and absorbing the local successfully continues along its line of progress. In other words, from all of the aforementioned, it emerges that for Protić Yugoslav is a product of, on the one hand, an intersection of discourses of an enlightened liberal-democratic provenance (with occasional statements of critical skepticism toward some of its aspects), and a blend of ideologies of a minimal and socialist Yugoslavism on the other (in spite of the fact that he takes as the starting points of modern art manifestations that emerged from an ideology of an integral Yugoslavism).

The MoCAB's Yugoslav orientation took precedence, if not conditioned by, then certainly compatible with, the ideological conceptualization of New Belgrade as the main administrative and executive center of the newly established socialist Yugoslavia, as well as with the fact that even the first urban plans included a building intended for the collection, documentation and representation of the "Yugoslav people's" modern/contemporary art-one more in a string of symbolic affirmations of the new movement, its relevance, atemporality and realization of the future in the present moment. ${ }^{40}$ On the other hand, this orientation gave Protic the opportunity for Serbian modern art to receive more adequate, complete, complex scientific-theoretical interpretation with respect to its conceptual, formal, exhibitional, (un)official and (non)institutional interconnection with phenomena in the artistic and cultural centers of Yugoslavia:

I defended that concept (then and later) from complaints that it meant a smaller exhibition space for Serbian art, that similar institutions in other national milieus do not show Serbian artists, that Yugoslavism in culture should be 'their' responsibility as well, not just

39 For example, Vera HORVAT PINTARIĆ, Pittura jugoslava d'oggi, La Biennale di Venezia, 35, 1959, pp. 15-24; Vera HORVAT PINTARIĆ, Jeunes artistes Yugoslaves, III Biennale de Paris, Musée d'art moderne de la ville de Paris, Paris 1963; Vera HORVAT PINTARIĆ, Suvremena jugoslavenska umjetnost, Civiltà delle macchine, 12/3, 1964, pp. 37-47; Vera HORVAT PINTARIĆ, Suvremena jugoslavenska umjetnost, Razlog, 5, 1964, pp. 455-465 reprinted in: Vera HORVAT PINTARIĆ, Kritike i eseji 1952.-2002. Izbor, Zagreb 2012, pp. 203-210; Matko MEŠTROVIĆ, Osobitost i univerzalnost. Jedan pogled u jugoslavensko slikarstvo posljednjeg decenija, Kolo, 2, 1964, pp. 64-70; Matko MEŠTROVIĆ, Od pojedinačnog općem, Zagreb 1967 (reprint Zagreb 2005); Vera HORVAT PINTARIĆ, Dimenzije slike. Tekstovi iz suvremene umjetnosti (ed. Zvonko Maković), Zagreb 2004, pp. 77-83.

40 For more on the conceptualization of the time in revolutionary societies, see Boris GROYS, The Total Art of Stalinism, Princeton 1992, pp. 14-74; Boris GROYS, Beyond Diversity. Cultural Studies and Its Post-Communist Other, Art Power (ed. Boris Groys), Cambridge, MA-London 2008, p. 154. 
'ours,' etc., and added that it is a shame that we cannot move forward and exhibit both Serbian and Yugoslav art in the context of the respective periods and poetics of European art. $^{41}$

In this way the MoCAB, in Protićs words, became for him as a critic an opportunity to "reconstruct, in our circumstances-in which modern art had not been studied in the fullest sensethe developmental process of Serbian and Yugoslav art of the 20th century," ${ }^{32}$ and to present, by editing the series on the Yugoslav art of the 20th century and writing the book Yugoslav Painting 1900-1950, the results of his research in a different medium, as a text/book, and in a different sphere, the scientific-theoretical. Protić often highlighted this vertical of Serbian art-Yugoslav artinternational art, defending the Yugoslav orientation of the MoCAB as an adequate and necessary framework for understanding Serbian modern art (and thus the book entitled Srpska arhitektura. 1900-1970 [Serbian Architecture, 1900-1970] will be published as part of the series on the Yugoslav art of the 20th century). ${ }^{43}$ Of course, such an explanation could be interpreted as the result of a pragmatic approach in an atmosphere that saw the beginnings of the political and ideological processes of the disintegration of Yugoslav socialist unity, which had included (at least in Tito's vision) the idea of a socialist country and the idea of a country of South Slavs, and in the direction of the strengthening of the idea of distinctive nations, i.e. the idea of the completeness of the nations, on the one hand, and advocating for the state's decentralization, i.e. the socialization of the state, ${ }^{44}$ the gradual replacement of the existent with the new, toward a classless and stateless society, on the other hand ${ }^{45}$-in other words, his explanation can be viewed from a different angle, in relation to the problematization of the Yugoslav answer to the Serbian (or Slovenian, or Croatian) question, and likewise the monopoly of power belonging to the nationally mixed yet centralized Party and the established system of rule, from the beginning of the 1960s.

The noun Yugoslavia (and the adjective Yugoslav) became the ideological keyword of the 20th century, a signifier that was omnipresent in public discourse. As with every signifier, it too acquired its identity through association with other existing signifiers, i.e. through the articulation of signifiers. Considering that a large number of speakers in the public sphere, members of different influential groups, invested meaning in this word in the interest of those groups, in the end the word became polysemic, a floating signifier (it lacks a written meaning; its concrete meaning is empty until a discourse invests it with its own interpretation), or even an empty signifier (a signifier without a sign that expresses the impossibility of signification). ${ }^{46}$ Protićs interpretation of the Yugoslav

41 Miodrag B. Protić 1983 (n. 25), p. 30; reprinted in: Prilozi 2016 (n. 15), p. 64.

42 Miodrag B. Protić 1983 (n. 25), p. 27; reprinted in: Prilozi 2016 (n. 15), p. 59. In 1960, Lazar Trifunović defended his doctoral thesis on the theme of Serbian painting in the first half of the 20th century. See above.

43 Srpska arhitektura 1900-1970 (ed. Miodrag B. Protić), Muzej savremene umetnosti, Beograd 1972. In addition, Protić edited a three-volume collection of essays on Serbian art theory and criticism between 1900 and 1950: Ideje srpske umetničke teorije i kritike. 1900-1950 (ed. Miodrag B. Protić), 1-3, Beograd 1980-1981. In the year that he retired from his position as director, the Museum of Contemporary Art published Nova umetnost u Srbiji. Pojedinci, pojave i grupe. 1970-1980 (eds. Ješa Denegri, Jadranka Vinterhalter), Muzej savremene umetnosti, Beograd 1983. Likewise, Protić gave his systematization of Serbian painting; see PROTIĆ 1970 (n. 21).

44 Dejan JOVIĆ, Communist Yugoslavia and Its "Others", Ideologies and National Identities. The Case of TwentiethCentury Southeastern Europe (eds. John Lampe, Mark Mazower), Budapest 2004, p. 283.

45 JOVIĆ 2003 (n. 37), pp. 132-154.

46 Ernesto LACLAU, Why do Empty Signifiers Matter to Politics?, Emancipation(s) (ed. Ernesto Laclau), London- 
in the syntagm Yugoslav art (of the 20th century) derived from different ideological positions (enlightened-liberal and socialist) and was structured by and subject to his belief in the universal, guiding, emancipatory, noble role of art in society; it was coherent and direct in matters of artistic production, and indirect, more implicit in relation to scientific-disciplinary and theoretical articulation. Thus, tracing the ideological context in which the MoCAB originates, as well as its Yugoslav conception as represented by its collection, permanent exhibition and "scholarly exhibitions" ${ }^{47}$ and their accompanying editions, one can defend the hypothesis that the ambitious, expert work on the MoCAB's conception and programming generated a narrative of the history of Yugoslav art of the 20th century, and also that the narrative, "reconstruction" and clearly methodologically articulated "systematization" were conceptually Yugoslav, just as the art that was the object of study. ${ }^{48}$

New York 2007, pp. 36-46. Ljiljana Kolešnik also speaks of the term "Yugoslav art" as an empty signifier, and says that the syntagm "Yugoslav art scene" points to an array of artistic phenomena loosely connected by a certain understanding of modernity that within the Yugoslav cultural space had a normative value until the end of the 1960s; see Ljiljana KOLEŠNIK, Hrvatska poslijeratna moderna umjetnost u jugoslavenskom kontekstu, Socijalizam i modernost. Umjetnost, kultura, politika 1950.-1974. (ed. Ljiljana Kolešnik), Muzej suvremene umjetnosti, Zagreb 2012, p. 135.

47 Miodrag B. PROTIĆ, Deset godina Muzeja savremene umetnosti u Beogradu. 1965-1975, Beograd 1975, p. 5.

48 The research and the completion of this study have been conducted in the scope of the project Serbian Art of the 20th Century: National and Europe, which has been funded by the Ministry of Education and Science of the Republic of Serbia. 


\section{Jugoslovansko: toponim ali ideologija v umetnostnozgodovinski sistematizaciji umetnosti 20. stoletja v besedilih Miodraga B. Protića}

Povzetek

Prispevek analizira ideološke okvire in zgodovinski kontekst v pred- in povojni Jugoslaviji, v katerih je Miodrag B. Protić (1922-2014) začel in uresničeval umetnostnozgodovinsko sistematizacijo umetnosti 20. stoletja. Protićevo delo je v veliki meri povezano z ustanovitvijo in delovanjem Muzeja sodobne umetnosti v Beogradu leta 1965. Avtorica problematizira uporabo pojma jugoslovansko v sintagmi jugoslovanska moderna umetnost. Pojem interpretira kot večpomenski, saj so njegove pomene izoblikovali različni diskurzi o jugoslovanski umetnosti in kulturi. V prispevku so predstavljeni in analizirani učinki uporabe tega pojma v Protićevih delih.

Miodrag B. Protić je bil pomembna osebnost kulturnega življenja Srbije in Jugoslavije v petdesetih, šestdesetih in sedemdesetih letih 20. stoletja. Odrastel je pod vplivom francoske kulture in modernizma, pod katerim se je tudi intelektualno izoblikoval. Bil je frankofil in frankofon. Po izobrazbi je bil pravnik, deloval pa je kot slikar, likovni kritik in teoretik, za katerega je bil značilen metodičen in pronicljiv kritiški slog. Bil je eden od glavnih pobudnikov ustanovitve beograjske Moderne galerije oziroma Muzeja za sodobno umetnost in njegov prvi ravnatelj. Ker je bil trdno prepričan v prosvetljeno in emancipatorsko vlogo moderne umetnosti, je verjel v (visoko)modernistične ideale o avtonomiji umetnosti, univerzalnosti njenega doživljanja, razumevanju umetniškega dela in umetnosti ter vrednotenju umetniških del izključno z vidika umetniške vrednosti dela. Verjel je namreč, da je napredna oziroma socialistična lahko le umetnost, ki je povsem svobodna in avtonomna. Protić je bil v svojih idejah blizu paradigmi modernistične umetnosti, ki je modernizem opredeljevala kot eksperimentalno, inovativno in avtonomno ustvarjalnost subjektivnih in racionalnih posameznikov. Prav tako je menil, da je moderna/sodobna umetnost avtentično moderna/sodobna le, če je mednarodnega značaja, pri čemer je koncept mednarodnega pojmoval kot okvir ali predpogoj za emancipacijo.

Leta 1959 - leto po ustanovitvi Moderne galerije, h kateri je kot uslužbenec Ministrstva za prosveto, znanost in kulturo Ljudske republike Srbije pomembno prispeval - je bil Protić imenovan za njenega direktorja. S tem je dobil priložnost, da uporabi svoje izkušnje in dobro poznavanje modernističnega slikarstva ter razviti čut za kritiko in teorijo umetnosti ter se ne posveti le konceptualiziranju muzeja samega, marveč prispeva tudi k umetnostnozgodovinskemu diskurzu in sintezi moderne umetnosti jugoslovanskega prostora. Do odhoda z mesta direktorja 1980 je v Muzeju sodobne umetnosti pripravil koncepte za več pomembnih študijskih razstav, ki so jih spremljali katalogi, izdani v knjižni seriji Jugoslovenska umetnost 20. veka. Razstave, ki so se osredotočala na umetnine in ne na umetnike, so bile $\mathrm{z}$ namenom, da bi učinkovito predstavile posamezna obdobja modernizma in njihove predstavnike, zasnovane kot »kronološko izmenjavanje poetičnih serij«. Protićev pristop je temeljil na teoretični analizi in proučevanju geneze umetnin, na študiju umetnine kot ene od možnih manifestacij posamezne, širše abstraktne strukture. Izhodišče Protićevih teoretičnih, kritičnih in umetnostnozgodovinskih interpretacij umetnin je utemeljeno na podlagi osebnih izkušenj in prepričanj modernistov, da so poetični vidiki umetniških del imanentni delu samemu ter integrirani v umetniško delo in proces njegovega ustvarjanja. V interpretacijah se je usmerjal k identificiranju, opisovanju in razlagi umetniških dejstev kot estetskih, na eni strani v smislu opažanja in interpretacije njihovih odnosov do konceptualiziranih, zgodovinsko opredeljenih »družin« podobnih umetniških del, na drugi strani glede na čas, v katerem so nastala, in pripadajočo mu zgodovino. V diahronični strukturi (znotraj katere Protić, upoštevajoč pluralizem kot osnovno načelo, pojave spoznava pravzaprav sinhrono) Protićevih spekulativnih povezav 
likovno-formalne analize s teoretičnimi jeziki (eksistencializmom, strukturalizmom, fenomenologijo) je namera, da bi proučeval umetnost $\mathrm{v}$ določenem časovnem obdobju, prostorsko/geografskih okvirih in njim pripadajočih kulturnozgodovinskih kontekstih oziroma da bi dekonstruiral kritiško-teoretsko pisanje o "poetičnih serijah « v poskus, osnutek, "skico « ali predlog umetnostnozgodovinskega narativa. Pozornost vzbuja odsotnost poimenovanja smeri (jugoslovanska umetnost 20. stoletja in ne npr. zgodovina jugoslovanske umetnosti 20. stoletja), v okvirih katere se opisujejo, analizirajo, interpretirajo in nato sistematizirajo proučevani fenomeni in koncepti, kar pa ni posledica strokovne negotovosti ali neodločnosti, temveč prej samoumevnosti znanstveno-teoretičnega okvira, v katerem poteka proučevanje umetnosti, in samoumevnosti produkcije s spoštovanjem do predmeta proučevanja.

Jugoslovanska orientiranost beograjskega Muzeja sodobne umetnosti je bila, če že ne povsem pogojena, pa vsekakor skladna z ideološkim pojmovanjem Novega Beograda kot glavnega administrativnega in upravnega središča novonastale socialistične Jugoslavije kot tudi z dejstvom, da so že prvi urbanistični načrti vključevali zgradbe, namenjene zbiranju, dokumentiranju in reprezentiranju moderne oziroma sodobne umetnosti »jugoslovanskega naroda « kot še enega doprinosa v vrsti simbolnega potrjevanja novega reda. Ta orientacija je po Protiću prinašala možnost, da srbska moderna umetnost dobi primernejšo, popolnejšo, kompleksno znanstveno-teoretično interpretacijo, upoštevajoč tako njeno konceptualno, formalno, razstavno, (ne)uradno, (zunaj)institucionalno prepletanje s pojavi v umetniških in kulturnih središčih Jugoslavije kot tudi osebne, poklicne in zasebne stike umetnikov iz jugoslovanskega kulturnega prostora, ki so pogosto nastali, se oblikovali in utrdili v mednarodnem ozračju evropskih umetniških in kulturnih centrov.

Po drugi strani pa Protićevo (razsvetljensko, modernistično) brezpogojno prepričanje v nevtralnost in objektivnost teoretičnih pristopov in znanstvenih disciplin, zaradi katerih se predpostavlja njihov breznacionalni značaj ali, natančneje, na osnovi katerih se predpostavlja nacionalni doprinos k Znanosti, ki pripada vsem, sproža vprašanje, ali se je smiselno spraševati, o čigavi umetnostni zgodovini govorimo. Če je bila jugoslovanska moderna umetnost predmet opisovanja in proučevanja in če je njeno raziskovanje potekalo dosledno s stališča zgodovinopisnega, formalno analitičnega in primerjalnega pristopa, ali bi bilo logično sklepati, da gre za neki metodološko utemeljen, koherenten narativ »jugoslovanske« zgodovine moderne umetnosti? Protić je z vsebino knjižne serije Jugoslovenska umetnost 20. veka implicitno najavil ta narativ, vendar pa ga je obenem $z$ njeno strukturo, če že ne zanikal, prav zagotovo postavil pod vprašaj: vsak katalog je razdrobljen na posamezne predstavitve umetnosti jugoslovanskih starih/ novih kulturno-umetniških središč, avtorji preglednih člankov pa so bili kolegi in kolegice iz sorodnih ustanov iz omenjenih središč. $Z$ drugimi besedami, struktura vsakega kataloga znotraj serije je ponavljala in odsevala politično delovanje federativne države po načelu t. i. republiškega ključa in tako predstavljala ozračje političnih in ideoloških procesov razpadanja jugoslovanske socialistične skupnosti, sproženih na začetku šestdesetih let 20. stoletja.

Protićeva interpretacija jugoslovanskega v besedni zvezi jugoslovanska umetnost (20. stoletja) je izvirala $\mathrm{z}$ različnih ideoloških stališč (razsvetljensko-liberalnega in socialističnega), strukturirana je bila po njegovem prepričanju, da ima umetnost $\mathrm{v}$ družbi univerzalno, pionirsko, emancipacijsko in plemenito vlogo, in je temu podrejena; ko se je njegova interpretacija nanašala na umetniško produkcijo, je bila koherentna, samozavestna in neposredna, $v$ odnosu do znanstveno-strokovne in teoretične artikulacije pa je bila posredna, bolj implicirana. Če torej upoštevamo ideološki kontekst, v katerem so nastali Muzej sodobne umetnosti in njegovi jugoslovanski koncepti, ki so bili predstavljeni z zbirko, stalno in študijskimi razstavami ter njihovo spremno zbirko publikacij, lahko zagovarjamo hipotezo, da je ambiciozno strokovno delo na zasnovi in programu Muzeja sodobne umetnosti generiralo narativ zgodovine jugoslovanske umetnosti 20. stoletja, kot tudi to, da je bil ta narativ (tj. »rekonstrukcija«, »sistematizacija«), ki je metodološko jasno artikuliran, jugoslovanski le konceptualno, ravno tako kot umetnost, ki je bila predmet raziskovanja. 
Oelgari na to Rimol

\section{Proicluta pur}

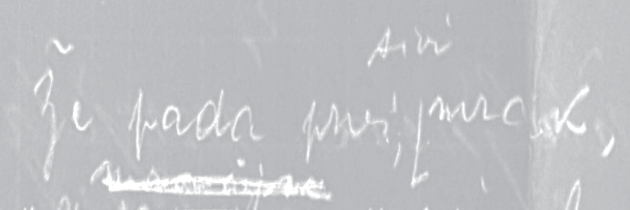

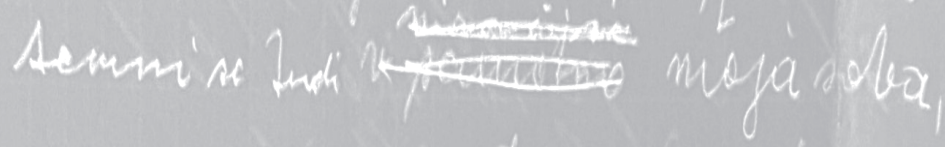

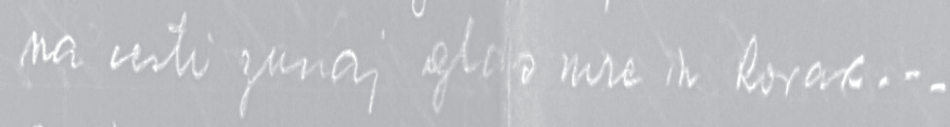

in ion sem karkat tredi groba.

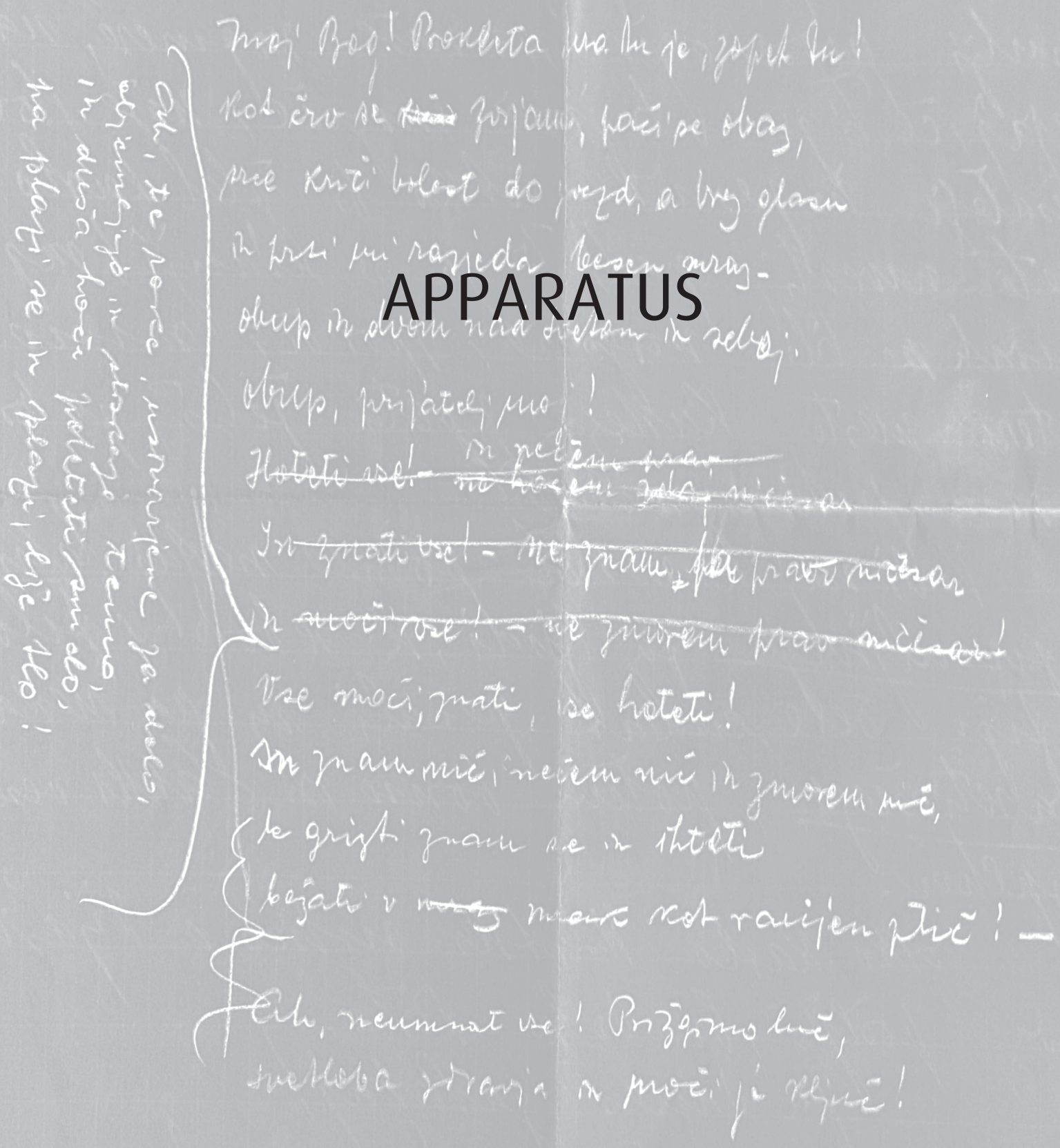

Sha ha ha ba: Ma muxi' mn' by: 



\section{IZVLEČKI IN KLJUČNE BESEDE}

\section{ABSTRACTS AND KEYWORDS}

\section{Jasmina Čubrilo}

Jugoslovansko: toponim ali ideologija v umetnostnozgodovinski sistematizaciji umetnosti 20. stoletja $v$ besedilih Miodraga B. Protića

\subsection{Izvirni znanstveni članek}

Prispevek analizira ideološki kontekst in zgodovinske okoliščine, v katerih je Miodrag B. Protić snoval in realiziral umetnostnozgodovinsko sistematizacijo pred- in povojne jugoslovanske umetnosti. Avtorica problematizira koncept »jugoslovansko « v sintagmi »jugoslovanska moderna umetnost « in ga interpretira kot večpomenko. Prispevek obravnava učinke različnih diskurzov o »jugoslavizmih« na Protićevo razumevanje koncepta.

Ključne besede: Miodrag B. Protič, jugoslovanska umetnost, moderna umetnost, sistematizacija umetnosti, Muzej sodobne umetnosti Beograd

\author{
Vesna Krmelj \\ France Stele v luči mladostne korespondence z Izidorjem \\ Cankarjem
}

\subsection{Izvirni znanstveni članek}

Prispevek obravnava korespondenco med dvema ključnima predstavnikoma dunajske umetnostnozgodovinske šole v slovenskem prostoru - Francetom Steletom in Izidorjem Cankarjem. Razprava sledi njunemu dopisovanju od začetka študija do konca leta 1913 in se osredotoča na Steletovo uredniško in javno delovanje v obdobju pred prvo svetovno vojno.

France Stele je kmalu po vpisu na Dunajsko univerzo prevzel uredništvo Zore, glasila katoliškega akademske-

\section{Jasmina Čubrilo}

Yugoslav: Toponym or Ideology in Miodrag B. Protićs

Art-Historical Systematization of 20th-Century Art

\subsection{Original scientific article}

The article analyzes the ideological context and historical circumstances in which Miodrag B. Protić initiated and realized the art-historical systematization of 20thcentury art from the territory of pre- and postwar Yugoslavia. The concept of "Yugoslav" in the syntagm "Yugoslav modern art" is problematized, interpreted here as a polysemy whose meanings were produced by various discourses about Yugoslavism; the effects of those found in Protić's articulations are mapped and examined.

Keywords: Miodrag B. Protić, Yugoslav art, modern art, art criticism, art systematization, Museum of Conteporary Art in Belgrade

\section{Vesna Krmelj}

An Insight into France Stele through his Early Adulthood Correspondence with Izidor Cankar

\subsection{Original scientific article}

The article deals with the correspondence between two key representatives of the Vienna School of Art History at the University of Ljubljana, France Stele and Izidor Cankar. The discussion follows their correspondence from the start of their studies until the end of 1913, and focuses on Stele's editorial and public activities in the pre-WW1 period. Soon after enrolling at the University of Vienna, France Stele became the editor of Zora, a bulletin of the Catholic Academic Society Danica and invited Cankar, who was 
ga društva, in k sodelovanju povabil Cankarja, ki je tedaj študiral v Louvainu. Stele in Cankar sta se spopadla s predsodki ob sprejemanju moderne umetnosti med slovenskimi katoliškimi izobraženci zlasti v primeru sodobne cerkvene arhitekture.

Steletov esej Apologija moderne umetnosti, objavljen leta 1911, lahko razumemo kot prvi neposredni naslon na dunajsko šolo umetnostne zgodovine. Vsebina članka in odzivi nanj sicer niso neposredno odmevali v ohranjeni korespondenci med Steletom in Cankarjem, vendar pa je sam način, kako sta se kolega kasneje dopolnjevala in podpirala, zelo značilen za njuno vodenje javne polemike.

Ključne besede: France Stele (1886-1972), Izidor Cankar (1886-1958), korespondenca, zgodovina umetnostne zgodovine, Dunajska umetnostnozgodovinska šola, slovenska umetnostna zgodovina, študentska društva, slovenski katoliški izobraženci, slovenski študenti na Dunaju

\section{Barbara Murovec \\ Historizirana podoba naročnika. Attemsova družinska portreta in Rembov avtoportret iz brežiškega gradu}

\subsection{Izvirni znanstveni članek}

V prispevku sta analizirana družinska portreta Ignaca Marije grofa Attemsa (Ljubljana, 15. avgust 1652 - Graz, 13. december 1732) s sinovi in Marije Regine grofice Wurmbrand, poročene Attems (Graz, 3. junij 1659 - Brežice, 24. april 1715) s hčerko in sinovoma, ki sta bila $\mathrm{v}$ oljni tehniki naslikana za veliko dvorano gradu Brežice (nem. Rann). Od leta 2010 sta hranjena v Dvorcu Eggenberg Deželnega muzeja Joanneum. Naslikal ju je Frančišek Karel Remb (Radovljica, 14. oktober 1674 - Dunaj, 23. september 1718), ki je sebe upodobil v celopostavni figuri $\mathrm{v}$ fresko tehniki na reprezentativnem mestu sredi dvorane, in sicer kot edino osebo iz sedanjosti. Ignac Marija, ki se je arhivsko izpričano udejstvoval kot arhitekt pri gradnji in prezidavah svojih bivališč, je na portretu predstavljen kot arhitekt-ustvarjalec in kot arhitekt-začetnik nove štajerske družine. Pretehtana inscenacija historiziranih portretov, s katerima sta želela ponosna starša za večnost ohraniti podobo umetnostno darežljive in ambiciozne družine, ki prosperira v miru in ljubezni, se nam v povezavi s slikarjevim avtoportretom kaže kot izjemna. Čeprav lahko pokažemo na številne mogoče vzore, so ti slikarju in naročniku služili le kot inspiracija za edinstveno umetniško celoto.

Ključne besede: Štajerska, Frančišek Karel Remb, Ignac Marija grof Attems, Marija Regina grofica Wurmbrand, družinski portret, avtoportret, naročnik-arhitekt, 1700, baročno slikarstvo studying in Louvain, to participate. After 1911, when both studied in Vienna, Stele and Cankar directly addressed prejudice on the acceptance of modern art among Slovene Catholic scholars, especially in cases of contemporary church architecture. Stele's essay "The Apology of Modern Art", published in 1911, can be understood as his first direct application of the principles of the Vienna School of Art History. The content and critical responses to the article were not directly recorded in the preserved correspondence between Stele and Cankar; however, the way in which the two colleagues later complemented and supported one another is highly characteristic of how they also led public discourse.

Keywords: France Stele (1886-1972), Izidor Cankar (1886-1958), correspondence, history of art history, the Vienna School of Art History, Slovenian art history, student associations, Slovene Catholic scholars, Slovenian students in Vienna

\section{Barbara Murovec \\ The Patron's Historized Image. Attems' Family Portraits and Remp's Self-Portrait in the Brežice (Rann) Castle}

\subsection{Original scientific article}

The paper analyzes the family portraits of Ignaz Maria, Count of Attems (Ljubljana/Ger. Laibach, 15 August 1652Graz, 13 December 1732), with his sons, and Maria Regina, Countess of Wurmbrand with her daughter and sons, painted in oil technique for the Great Hall in the Brežice Castle (Ger. Rann). The portraits have been kept at Schloss Eggenberg of the Landesmuseum Joanneum since 2010. They were painted by Franz Carl Remp (Radovljica/Ger. Radmannsdorf, 14 October 1674-Vienna, 23 September 1718), who depicted himself in fresco technique in full figure in a representative place in the center of the hall as the only person from the present. In the portrait, Ignaz Maria, who, according to archival sources, participated as an architect in the construction and rebuilding of his residences, is presented as an architect-creator and an architect-founder of the new Styrian family. A careful arrangement of historized portraits, with which the proud parents wanted to preserve for eternity the image of an artistically generous and ambitious family that prospers in peace and love, in connection to the painter's self-portrait, is exceptional. Even though numerous possible sources for the paintings can be named, they served only as an inspiration for a unique work of art.

Keywords: Styria, Franz Carl Remp, Ignaz Maria, Count of Attems, Maria Regina, Countess of Wurmbrand, family portrait, self-portrait, patron-architect, 1700, Baroque painting 


\section{Mija Oter Gorenčič}

Pro remedio et pro salute animae nostrae.

Memoria v srednjeveškem umetnostnem okrasju cisterce

$v$ Stični kot odsev tesne povezanosti s plemstvom

\subsection{Izvirni znanstveni članek}

Članek prinaša sistematičen pregled nad listinskimi omembami pokopov laikov v cistercijanskem samostanu Stična in njihovim vplivom na umetnostno zasnovo cisterce. Najstarejši dokaz povezav s plemstvom je krog z grbovnim ščitkom tik nad nekdanjim nišnim grobom v severovzhodnem kotu križnega hodnika ob prvotnem meniškem vhodu v cerkev. Naslikan je bil pred obokanjem križnega hodnika, ki se postavlja $\mathrm{v}$ čas okrog leta 1228. Do tega leta arhivski viri med pokopanimi v samostanu omenjajo le soustanovitelje samostana, Višnjegorske grofe in njihovo rodbino. Po sredini 13. stoletja so v skladu s prakso v drugih cistercijanskih samostanih pokopi laikov postali pogostejši. Najstarejša listina, ki se najverjetneje nanaša na pokop laika v cerkvi, sega v leto 1293. Avtorica v članku argumentirano podaja številne nove interpretacije in razpravlja o identifikaciji grbov, mestu, kjer so bili pokopani soustanovitelji samostana, identifikaciji oseb, ki so bile pokopane v pokopališki kapeli, in nišnem grobu pod najstarejšim grbom v križnem hodniku.

Ključne besede: cistercijanski samostan Stična, plemstvo, srednji vek, pokopi, križni hodnik, grbi, nagrobniki, nišni grob, turjaška kapela, Auerspergi, Višnjegorski, Čreteški, Svibenski

\section{Friedrich Polleroß}

Brezmadežna, cesar Leopold I. in rimski tezni list ljubljanskih frančiškanov

\subsection{Izvirni znanstveni članek}

Članek obravnava tezni list Jana Onghersa iz leta 1700, ki je bil doslej neznan oz. smo poznali le pripravljalno risbo zanj, hranjeno v Budimpešti. Grafika vključuje naslednje ikonografske teme: habsburško češčenje Brezmadežne, zmagoslavje nad Otomani, rivalstvo med frančiškanskim ter jezuite in njihove tezne liste. Obenem osvetljuje politično-umetnostne zveze med Dunajem, Ljubljano, Augsburgom in Prago.

Ključne besede: Pietas Austriaca, Brezmadežna, Habsburžani, tezni listi, frančiškani, dominikanci, jezuiti, Joannes Duns Scotus, Otomani, Jan Onghers, Elias Nessenthaler

\author{
Mija Oter Gorenčič \\ Pro remedio et pro salute animae nostrae. \\ Memoria in Medieval Architectural Decoration of the \\ Stična Cistercian Monastery as a Reflection of its Close \\ Connection with the Nobility
}

\subsection{Original scientific article}

The paper offers a systematic overview of the documented burials of laymen in the Cistercian monastery in Stična and of their influence on the artistic design of the monastery. The oldest proof of its connection to nobility is a circle with a coat-of-arms above the former tomb niche in the northeastern corner of the cloister, next to the original monastic entrance to the church. It was painted before the vaulting of the cloister, which is dated around 1228. According to archival sources, until that year, only the co-founders of the monastery, the Counts of Weichselberg, and their families were buried in the monastery. After the middle of the 13th century, the burials of laymen became more frequent, in accordance with the practice in other Cistercian monasteries. Probably the oldest document referring to the burial of a layman in the church dates back to 1293 . The authoress of the paper argues several new interpretations and discusses identifications of the coat of arms, the monastery co-founders' locations of burial, the identification of persons, who were buried in the burial chapel, and the tomb niche under the oldest coat-of-arms placed in the cloister.

Keywords: Cistercian monastery Stična, nobility, Middle Ages, burials, cloister, coats-of-arms, tombstones, arcosolium, Auersperg chapel, Lords of Auersperg, Counts of Weichselberg, Lords of Reitenburg, Lords of Scharffenberg

\section{Friedrich Polleroß}

The Immaculata, Emperor Leopold I, and a Roman

Thesis Print by the Franciscans from Ljubljana

\subsection{Original scientific article}

The paper presents a Roman thesis print by Jan Onghers from 1700 that had been unknown until now; we only knew its preparatory drawing in Budapest. The graphic combines different themes: the veneration of the Immaculata by the House of Habsburg, the triumph over the Ottomans, the rivalry between the Franciscans, and Jesuits and their influence on the development of thesis prints. Moreover, it discusses the political and artistic relations among Vienna, Ljubljana, Rome, Augsburg and Prague.

Keywords: Pietas Austriaca, Immaculata, Habsburg, Thesis Print, Franciscans, Dominicans, Jesuits, Joannes Duns Scotus, Ottomans, Jan Onghers, Elias Nessenthaler 


\author{
Damjan Prelovšek \\ Plečnikov prizidek $k$ bratovi hiši $v$ Trnovem
}

1.01 Izvirni znanstveni članek

Vpogled v doslej neprebrano arhitektovo pisemsko zapuščino in nekatere druge zgodovinske vire temeljito spreminja vedenje o nastanku in opremi Plečnikovega domovanja v Trnovem. Glavni namen gradnje valjastega prizidka (1923-1924), ustvariti skupen dom za brate in sestro, se ni posrečil zaradi njihovih različnih življenjskih usod. Sprva so se vsi navduševali za hišo na sedanjem Ciril-Metodovem trgu 10, v kateri je stanovala sestra, a se je Andrej Plečnik po vrnitvi iz Idrije raje odločil za nakup hiše za trnovsko cerkvijo v Ljubljani. Popraviti je treba tudi trditev, da naj bi se Jože sprl z najmlajšim Janezom, nakar naj bi ta zapustil hišo v Trnovem. V resnici oba v njej nikoli nista skupaj stanovala. Tudi starejši Andrej svoje posesti ni dolgo užival, ker ga je disciplinska komisija spodila iz ljubljanske realke, na kateri je poučeval verouk. Odšel je za kateheta v Kočevje in se ni nikoli več za stalno vrnil v Ljubljano. Na koncu je arhitekt $\mathrm{v}$ hiši ostal sam in si jo po svoje opremil.

Ključne besede: arhitektura 20. stoletja, Jože Plečnik, Andrej Plečnik, Janez Plečnik, Marija Matkovič, adaptacija Gabrovkine hiše, hiša v Trnovem, načrt prizidka, oprema prizidka, utopija o skupnem domu.

\section{Janez Premk \\ Mariborska sinagoga pod drobnogledom}

\subsection{Pregledni znanstveni članek}

Mariborska sinagoga spada med najpomembnejše ohranjene srednjeveške sinagoge v Srednji Evropi. Od prenove oziroma delne rekonstrukcije v letih 19921999 dalje objekt služi v kulturne namene. Prenova, ki je potekala pod vodstvom ZVKDS, se je izkazala za veliko zahtevnejšo, kot se je sprva predvidevalo. Izvedene prenove vsaj v strokovni literaturi niso problematizirali in je služila tako po arhitekturni lupini kot stavbnih elementih za referenčni primer pri poskusih (vizualnih) rekonstrukcij sorodnih spomenikov v tujini. Vendar je že sama prenova pustila veliko odprtih vprašanj, predvsem kar se tiče stavbnih faz v času judovske in kasneje krščanske uporabe stavbe. $V$ članku je predstavljena zgodovina spomeniškovarstvene dokumentacije in po-

\author{
Damjan Prelovšek \\ Jože Plečnik's Extension of his Brother Andrej's House \\ in Trnovo
}

1.01 Original scientific article

Insight into the architect's previously unread epistolary heritage and some other historical sources profoundly changes our knowledge about the origin and furnishings of Plečnik's home in Trnovo. The main reason for the construction of the cylindrical extension (1923-1924) was to create a common home for the brothers and sister, but it was not successful because of their different destinies. At first, they were all enthusiastic about the house at present-day 10 Ciril-Metod Square, where the sister lived, however, when Andrej Plečnik returned from Idrija, he decided to buy a house behind the Trnovo church in Ljubljana. The claim that Jože quarrelled with the youngest Janez, who then left the house in Trnovo, also needs to be corrected. In reality, they never lived there together. Moreover, the older brother Andrej did not enjoy his property for long, since the disciplinary committee drove him away from the Ljubljana Realschule, where he taught catechesis. He left to be a catechetic in Kočevje and never permanently returned to Ljubljana. In the end, the architect remained alone in the house and furnished it according to his own liking.

Keywords: 20th century architecture, Jože Plečnik, Andrej Plečnik, Dr. Janez Plečnik, Marija Matkovič, Terezija Gaber's house, Plečnik house in Trnovo, extension plans, extension furnishings, utopia of a common home

\section{Janez Premk \\ Maribor Synagogue Reexamined}

\subsection{Review Article}

The Maribor Synagogue is one of the most important preserved medieval synagogues in Central Europe. Since undergoing renovation and partial reconstruction from 1992-1999, the facility has served as a cultural centre. The renovation, which was supervised by the ZVKDS (Institute for the Protection of Cultural Heritage of Slovenia), proved to be much more demanding than was originally foreseen. While the outcome of the renovation has not been scrutinised in professional literature, its architectural shell and elements have served as a reference point for the (visual) reconstruction attempts of similar monuments abroad. However, the renovation itself has left numerous unanswered questions, especially in regard to the building phases during the Jewish and later Christian 
segov na objektu v 20. stoletju v luči napredka stroke pri raziskavah srednjeveških sinagog. Na primeru sporne interpretacije nekaterih stavbnih členov in neupoštevanja arheoloških raziskav je postavljena pod vprašaj celotna rekonstrukcija.

Ključne besede: judovska dediščina, sinagogalna arhitektura, srednjeveške sinagoge, srednja Evropa, Maribor, spomeniško varstvo

\section{Tanja Zimmermann}

Oto Bihalji-Merin in koncept »naivnih « v petdesetih letih 20. stoletja. Most med socialističnim realizmom in nefiguralno umetnostjo

\subsection{Izvirni znanstveni članek}

Jugoslovanski pisatelj, umetniški kritik in kustos Oto Bihalji-Merin (1904-1993) je v dvajsetih letih prejšnjega stoletja živel v Berlinu, kjer se je pridružil nemški komunistični partiji in objavljal literarno kritiko v levičarskem tisku pod sovjetskim vplivom. Rojen v židovski družini $\mathrm{v}$ Zemunu, je po vzponu nacističnega režima $\mathrm{v}$ tridesetih letih emigriral najprej v Češkoslovaško, potem pa v Francijo in Švico. Ob izbruhu druge svetovne vojne se je kot jugoslovanski vojak znašel v nemškem ujetništvu. Po vojni je postal eden najpomembnejših kulturnih teoretikov in administratorjev v Titovi Jugoslaviji. Po sporu Tita s Stalinom je postal goreč zagovornik naivne ljudske umetnosti kot prvobitnega in pristnega izraza proletarske in kmečke ustvarjalnosti. Merinova doktrina, ki je služila za premostitev razlik med socialističnim realizmom in zahodno nefiguralno umetnostjo, je temeljila na teoretskih idejah o tretji poti Mirolsava Krleže in gibanju neuvrščenih.

Ključne besede: Oto Bihalji-Merin, naivni, primitivni, socialistični realizem, nefigurativno slikarstvo, abstrakcija, »tretja pot«, Expo 58, gibanje neuvrščenih, Jugoslavija use of the building. The article examines the history of the monument's documentation and preservation in the 20th century in light of recent progress in medieval synagogue research. Owing to the controversial interpretations of certain architectural elements and the failure to take archaeological research into account, the entire reconstruction is called into question.

Keywords: Jewish heritage, synagogue architecture, medieval synagogues, Central Europe, Maribor, heritage protection

\section{Tanja Zimmermann}

Oto Bihalji-Merin and the Concept of the "Naïve" in the 1950s. Bridging Socialist Realism and Non-Figurative Art

\subsection{Original scientific article}

Yugoslav writer, art critic and curator Oto Bihalji-Merin (1904-1993) lived in Berlin during the 1920s, where he joined the German Communist Party and published literary critique in the left-wing press. Born into a Jewish family, he moved to Czechoslovakia, France, Switzerland, and Spain after the rise of the Nazi regime. In this period, he established close contact with left-wing intellectuals from all over Europe. During the Second World War, he was imprisoned as a Yugoslav soldier by the Germans. After the war, he became the most important cultural theorist and administrator in Tito's Yugoslavia. After Tito's break with Stalin, he promoted the concept of naïve folk art as an authentic, primordial expression of proletarian and peasant creativity. His doctrine, destined to bridge the gap between socialist realism and Western non-figurative art, was inspired by Miroslav Krleža’s cultural theory of the Third Way and by the non-aligned movement.

Keywords: Bihalji-Merin, naïve, primitive, socialist realism, non-figurative art, abstraction, Third Way, Expo 58, Non-Aligned Movement, Yugoslavia 



\section{SODELAVCI}

\section{CONTRIBUTORS}

Izr. prof. dr. Jasmina Čubrilo

Odeljenje za istoriju umetnosti

Filozofski fakultet

Univerzitet u Beogradu

18-20 Čika Ljubina Street

SR-11000 Beograd

jasmina.cubrilo@f.bg.ac.rs

\author{
Akad. prof. dr. Milček Komelj \\ Glinškova ploščad 20e \\ SI-1000 Ljubljana \\ sumi.komelj@gmail.com
}

\section{Vesna Krmelj}

ZRC SAZU, Umetnostnozgodovinski inštitut

Franceta Steleta

Novi trg 2

SI-1000 Ljubljana

vesna.krmelj@zrc-sazu.si

Izr. prof. dr. Barbara Murovec

ZRC SAZU, Umetnostnozgodovinski inštitut

Franceta Steleta

Novi trg 2

SI-1000 Ljubljana

Bamurovec@zrc-sazu.si

\section{Doc. dr. Mija Oter Gorenčič}

ZRC SAZU, Umetnostnozgodovinski inštitut

Franceta Steleta

Novi trg 2

SI-1000 Ljubljana

moter@zrc-sazu.si

\author{
Dr. Friedrich Polleroß \\ Institut für Kunstgeschichte \\ Die Historisch-Kulturwissenschaftliche Fakultät \\ Universität Wien \\ Garnisongasse 13, Universitätscampus Hof 9 \\ A-1090 Wien \\ friedrich.polleross@univie.ac.at
}

\author{
Dr. Damjan Prelovšek \\ Zarnikova ulica 11 \\ SI-1000 Ljubljana \\ damjan.prelovsek@zrc-sazu.s
}

\section{Dr. Janez Premk}

Raziskovalno dokumentacijski center JAS

Poljanski nasip 52

SI-1000 Ljubljana

janez.premk@jas-center.eu

Prof. dr. dr. Tanja Zimmermann

Institut für Kunstgeschicte

Fakultät für Geschichte, Kunst und

Orientwissenschaften

Universität Leipzig

Dittrichring 18-20

D-04109 Leipzig

tanja.zimmermann@uni-leipzig.de 



\section{VIRI ILUSTRACIJ \\ PhOTOGRAPHIC CREDITS}

Jasmina Čubrilo

1: Arhiv družine Protić.

2-5: J. Čubrilo.

\section{Milček Komelj}

1-18: @ ZRC SAZU, Umetnostnozgodovinski inštitut Franceta Steleta, Ljubljana (fototeka).

\section{Vesna Krmelj}

1: Arhiv avtorice.

2: ๑ ZRC SAZU, Umetnostnozgodovinski inštitut Franceta Steleta, Ljubljana (fototeka).

3-6: ๑ Biblioteka SAZU.

\section{Barbara Murovec}

1: Arhiv Občine Brežice

2, 9: @ ZRC SAZU, Umetnostnozgodovinski inštitut Franceta Steleta, Ljubljana

(foto: Andrej Furlan).

3: Biblioteca comunale degli intronati, Siena.

4, 6: ๑ ZRC SAZU, Umetnostnozgodovinski inštitut Franceta Steleta, Ljubljana (fototeka).

5, 7: ๑ Schloss \& Park Eggenberg/Universalmuseum Joanneum GmbH.

8: ( ) INDOK center, Ministrstvo za kulturo Republike Slovenije.

10: https://commons.wikimedia.org/wiki/File:Jean_Nocret_-_Louis_XIV_et_la_famille_royale_-_

Google_Art_Project.jpg

\section{Mija Oter Gorenčič}

1, 3, 5, 7, 10, 11, 12, 13, 14, 17, 20, 21: ๑ ZRC SAZU, Umetnostnozgodovinski inštitut Franceta Steleta, Ljubljana (foto: Andrej Furlan).

2, 6, 8, 9, 18, 19: @ INDOK center Ministrstva za kulturo RS, Ljubljana.

4: J. W. Valvasor, Topographia Ducatus Carnioliae Modernae, Bogenšperk 1679.

15, 16: Barbara Žabota.

\section{Friedrich Polleroß}

1: ๑ Österreichische Nationalbibliothek, Dunaj.

2-5, 7, 11: F. Polleroß.

6: () Narodna galerija, Ljubljana (foto: Bojan Salaj).

8: @ Magyar Nemzéti Muzeum, Budimpešta.

9: Wikimedia Commons. 


\section{Damjan Prelovšek}

1-9, 11-12, 15: (C) Muzej in galerija mesta Ljubljane, Plečnikova zbirka, Ljubljana.

10: zasebna zbirka.

13-14, 16: (C) Muzeum hlavního města Prahy, Praga.

\section{Janez Premk}

1: Wikipedia, open source, (c) CC CY-SA 4.0.

2, 24-26, 29: (c) Raziskovalno-dokumentacijski center JAS, Ljubljana (foto: Janez Premk).

3: Wikimedia commons, (c) Peter Lauppert - CC By-SA 3.0 at.

4-8, 17: (c) Raziskovalno-dokumentacijski center JAS, Ljubljana (risba: Anja Premk).

9: (c) ZRC SAZU, Umetnostnozgodovinski inštitut Franceta Steleta, Ljubljana.

10-13: (c) INDOK center Ministrstva za kulturo RS, Ljubljana.

14-16, 19: (c) Pokrajinski arhiv Maribor.

18: (c) Steiermärkisches Landesarchiv, Graz.

20-23, 27: (c) Zavod za varstvo kulturne dediščine RS, Območna enota Maribor.

28: (c) ZRC SAZU, Umetnostnozgodovinski inštitut Franceta Steleta, Ljubljana (foto: Andrej Furlan).

\section{Tanja Zimmermann}

1-2: 50 Jahre moderne Kunst, Köln 1959.

3-4: O. Bihalji-Merin, Tradition und Perspektiven, Jugoslawien. Zeitgenössische jugoslawische Malerei, Beograd 1957. 

Vse pravice pridržane. Noben del te izdaje ne sme biti reproduciran, shranjen ali prepisan v kateri koli obliki oz. na kateri koli način, bodisi elektronsko, mehansko, s fotokopiranjem, snemanjem ali kako drugače, brez predhodnega dovoljenja lastnika avtorskih pravic (copyright).

All rights reserved. No part of this publication may be reproduced, stored in a retrieval system or utilized in any form or by any means, electronic or mechanical, including photocopying, recording or otherwise, without prior permission of the copyright owner.

Za avtorske pravice reprodukcij odgovarjajo avtorji objavljenih prispevkov.

The copyrights for reproductions are the responsibility of the authors of published papers. 


\section{ACTA HISTORIAE ARTIS SLOVENICA 23|1・ 2018}

\section{Vsebina $\cdot$ Contents}

Milček Komelj, Ob 70-letnici Umetnostnozgodovinskega inštituta Franceta Steleta. Nagovor na slavnostni akademiji 14. decembra 2017 v Prešernovi dvorani SAZU • France Stele Institute of Art History's 70th Anniversary. The Opening Speech at the Celebration on 14 December 2017 at the Prešeren Hall SAZU

Mija Oter Gorenčič, Pro remedio et pro salute animae nostrae. Memoria v srednjeveškem umetnostnem okrasju cisterce v Stični kot odsev tesne povezanosti s plemstvom • Pro remedio et pro salute animae nostrae. Memoria in Medieval Architectural Decoration of the Stična Cistercian Monastery as a Reflection of its Close Connection with the Nobility

Janez Premk, Maribor Synagogue Reexamined • Mariborska sinagoga pod drobnogledom

Friedrich Polleroß, Die Immaculata, Kaiser Leopold I., und ein römisches Thesenblatt der Laibacher Franziskaner • Brezmadežna, cesar Leopold I. in rimski tezni list ljubljanskih frančiškanov

Barbara Murovec, Historizirana podoba naročnika. Attemsova družinska portreta iz brežiškega gradu in Rembov avtoportret • The Patron's Historized Image. Attems' Family Portraits and Remp's Self-Portrait in the Brežice (Rann) Castle

Vesna Krmelj, France Stele v luči mladostne korespondence z Izidorjem Cankarjem • An Insight into France Stele through his Early Adulthood Correspondence with Izidor Cankar

Tanja Zimmermann, Oto Bihalji-Merin and the Concept of the "Naìve" in the 1950s. Bridging Socialist Realism and Non-Figurative Art • Oto Bihalji-Merin in koncept "naivnih« v petdesetih letih 20. stoletja. Most med socialističnim realizmom in nefiguralno umetnostjo

Jasmina Čubrilo, Yugoslav: Toponym or Ideology in Miodrag B. Protic's Art-Historical Systematization of 20thCentury Art • Jugoslovansko: toponim ali ideologija v umetnostnozgodovinski sistematizaciji umetnosti 20. stoletja v besedilih Miodraga B. Protića

Damjan Prelovšek, Plečnikov prizidek k bratovi hiši v Trnovem • Jože Plečnik's Extension of his Brother Andrej's House in Trnovo

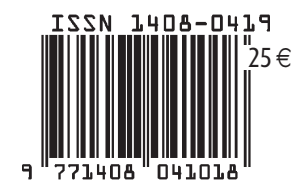

